\title{
Evolution of Non-metallic Inclusions Through Processing in Ti-V Microalloyed 316L and Al-V Microalloyed 17-4PH Stainless Steels for Hipping Applications
}

\author{
MARÍA J. BALART, XINJIANG HAO, SAMUEL MARKS, GEOFF D. WEST, \\ MARC WALKER, and CLAIRE L. DAVIS
}

\begin{abstract}
Powders produced by air-melted gas atomization (AMGA) and vacuum induction gas atomization (VIGA) from Ti-V microalloyed 316 and Al-V microalloyed 17-4PH stainless steels along with their feedstock material and Hot Isostatically Pressed (HIP'd) products have been examined. Inclusion characteristics and development through process along with changes in grain size have been characterized. The main findings are that a thin oxide film forms on the powder surface, thicker for the $316 \mathrm{~L}$ powder than the $17-4 \mathrm{PH}$ powder as indicated by XPS analysis of selected powder precursors, and large inclusions (predominantly oxides) are also observed on the $316 \mathrm{~L}$ powder. This results in a high number of inclusions, including more complex two-phase inclusions, on the prior particle boundaries in the HIP'd material. Grain growth occurs during HIPping of the $316 \mathrm{~L}$ powders with some evidence of inclusions locally pinning boundaries. In the vacuum-melted powder, smaller Ti-rich inclusions are present which give more grain boundary pinning than in the air-melted powder where Ti was lost from the material during melting. Consideration has also been made to determine the variation of $\mathrm{Ti}$ and $\mathrm{V}$ microalloying elements and residual $\mathrm{Cu}$ through processing. It was found that $\mathrm{Ti}$ was lost during air melting but partly retained after vacuum melting leading to the presence of fine and complex Ti-containing precipitates which provided grain boundary pinning during HIPping and heat treatment. V was retained in the melt by the use of both AMGA and VIGA processes, and therefore available for precipitation during HIPping. Residual $\mathrm{Cu}$ was retained during both air and vacuum melting and was associated with $\mathrm{Mn} \mathrm{S}$ and $\mathrm{Mn} \mathrm{O}$ S inclusions overwhelmingly outweighing that of Mn O inclusions in the two HIP'd 316L samples.
\end{abstract}

https://doi.org/10.1007/s11661-020-06010-w

(C) The Author(s) 2020

MARÍA J. BALART is with the University of Warwick, WMG Advanced Manufacturing and Materials Centre (AMMC), Coventry CV4 7AL, UK and also with the BCAST, Brunel University London, Uxbridge, Middlesex UB8 3PH, UK Contact e-mail: Maria.Balart@brunel.ac.uk XINJIANG HAO is with the University of Warwick, WMG - Advanced Manufacturing and Materials Centre (AMMC) and also with Liberty Powder Metals, Materials Processing Institute, Eston Road, Middlesbrough TS6 6US, UK. SAMUEL MARKS is with the University of Warwick, WMG - Advanced Manufacturing and Materials Centre (AMMC) and also with the Oxford Instruments NanoAnalysis, High Wycombe, Buckinghamshire HP12 3SE, UK. GEOFF D. WEST and CLAIRE L. DAVIS are with the University of Warwick, WMG - Advanced Manufacturing and Materials Centre (AMMC). MARC WALKER is with the Department of Physics, University of Warwick, Gibbet Hill Road, Coventry CV4 7AL, UK.

Manuscript submitted March 23, 2020.

Article published online October 12, 2020

\section{INTRODUCTION}

316L and 17-4PH stainless steels are versatile materials being used in many industrial sectors such as offshore, marine, aerospace, nuclear, chemical, and bioengineering due to their good combination of mechanical properties and corrosion resistance. ${ }^{[1]}$ Recently, several investigations have highlighted the potential of HIP'd 316L steel for the fabrication of pressure retaining components for nuclear reactors. ${ }^{[2-5]}$ Growth in the powder metallurgy sector ${ }^{[6-12]}$ has led to a considerable increase in the complexity of alloys, products, and processing routes, in particular the metallic powder supply chain. ${ }^{[13]}$

One of the main factors to take into consideration in metallic powders is that most steel alloying elements such as $\mathrm{Cr}, \mathrm{Mn}, \mathrm{Ti}, \mathrm{V}, \mathrm{Si}$, and $\mathrm{Al}$ are highly reactive to oxygen when exposed to air or other oxygen containing atmospheres and can spontaneously oxidize even under high vacuum conditions. ${ }^{[14]}$ Metallic elements can also 
spontaneously combine with sulfur. This can be typified by the Ellingham diagrams for oxides and sulfides. ${ }^{[15]}$ Surface oxidation of the molten steel droplets is unavoidable during atomization as oxide films easily form at the free surface of liquid metal. Powder precursors from stainless steel can be produced by a wide range of gas atomization techniques and generally have a high surface purity, particularly for vacuum induction gas atomization (VIGA). However, the surfaces can become degraded when the unused powder is recycled after additively manufacturing (AM), for example, the formation of sub-micron-sized $(<200$ $\mathrm{nm}) \mathrm{Cr}-\mathrm{Mn}$-Si-rich oxide particulates has been reported on recycled VIGA powder after AM by electron beam melting (EBM) and laser sintering (LS) processing. ${ }^{[16]}$ In addition, HIP'd 316L steel can contain endogenous oxidation products, along with deoxidation products, which mean that the steel product will contain a large number of non-metallic inclusions. ${ }^{[17,18]}$ The presence of non-metallic inclusions can harmfully affect the mechanical and corrosion properties of the steel and are therefore important to characterize and control.

Quasi-automated and automated SEM/EDS analyses have been extensively used among academia, ${ }^{[19-24]}$ industry, ${ }^{[25-27]}$ and other organizations ${ }^{[29]}$ in the last few years for non-metallic inclusions characterization for clean steelmaking and quality control. In particular, $\mathrm{SEM} / \mathrm{EDS}$ in conjunction with statistical data analysis has recently been proposed by Santecchia et al. ${ }^{[22]}$ for evaluation and benchmarking aiming at standardization, quality control, and quality assurance.

Composition vs depth profile measurements on $316 \mathrm{~L}$ powder surfaces were analyzed, in the 1980s, by Auger electron spectroscopy on water-atomized $316 \mathrm{~L}$ pow$\operatorname{der}^{[29]}$ and, more recently, by XPS as exemplified in Reference 16. In the water-atomized case, it was found that $\mathrm{Si}$ has a higher affinity to oxygen than $\mathrm{Cr}$ at high melting temperatures as well as high mobility in the liquid melt, and preferably oxidizes and migrates to the surface of the liquid $316 \mathrm{~L}$ steel. ${ }^{[29]}$ These results were confirmed by Hedberg et al. ${ }^{[30]}$ However, in the gas-atomized case of Reference 16, a very thin surface, iron oxide layer was formed in between the $\mathrm{Cr}-\mathrm{Mn}$-Si-rich surface oxide particulates. The very thin surface iron oxide layer was reported to be $2.9 \mathrm{~nm}$ in the as-atomized condition and $2.6 \mathrm{~nm}$ in the recycled powder condition. ${ }^{[16]}$ Hedberg et al. ${ }^{[30]}$ reported in the same study an Fe-rich layer, possibly $\mathrm{Fe}_{2} \mathrm{O}_{3}$, and that oxides on the surface of inert gas-atomized $316 \mathrm{~L}$ powders were found to be enriched in $\mathrm{Mn}, \mathrm{Fe}$, and $\mathrm{S}$ nanoparticles (20 to 200 $\mathrm{nm})$. As highlighted in their work, ${ }^{[30]}$ the surface microchemistry and stability depend on the steel alloy composition and key process parameters which are explicitly the cooling rate during atomization, the type of atomization, and the oxygen concentration in the atomization atmosphere.

Cooper et al..$^{[3-5,31]}$ conducted comparative studies between forged and HIP'd 304L and 316L steels. The oxygen content in the $304 \mathrm{~L}$ steel was $15 \mathrm{wt}$ ppm in the forged material compared with $110 \mathrm{wt} \mathrm{ppm}$ in the powder sample and $120 \mathrm{wt}$ ppm in the HIP'd sample. ${ }^{[3,31]}$ The oxygen content in the $316 \mathrm{~L}$ steel was $23 \mathrm{wt}$

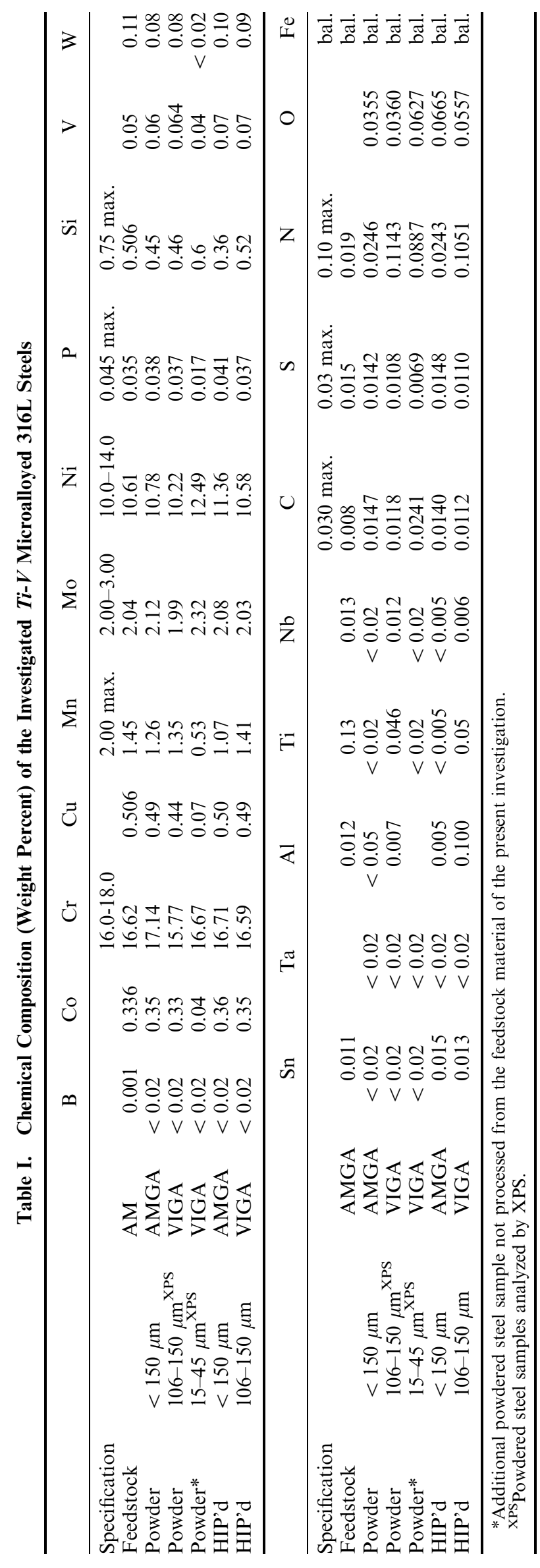




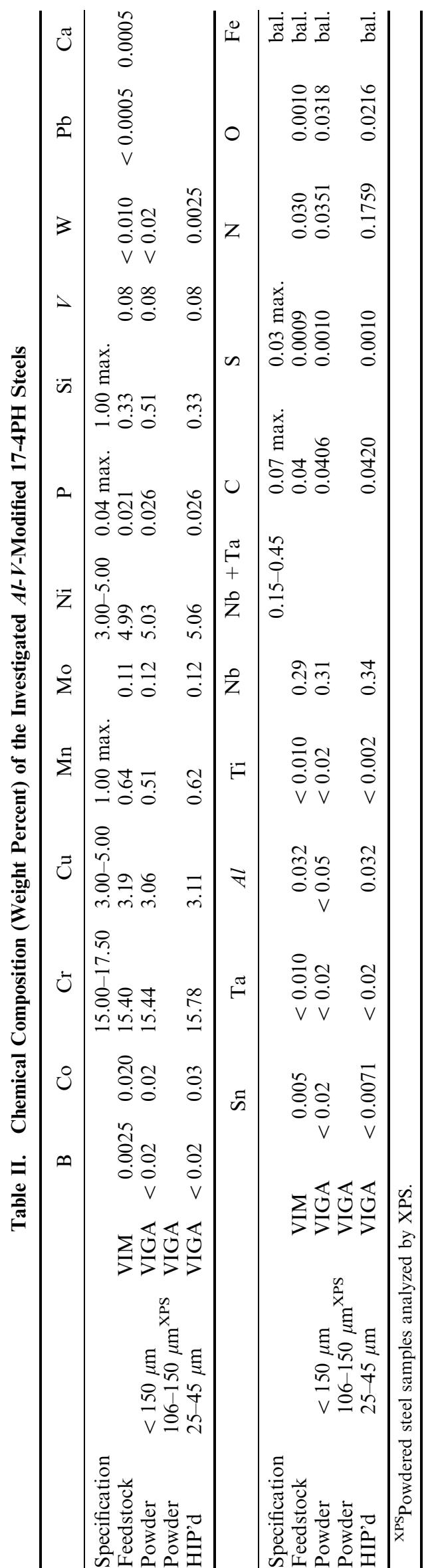

ppm in the forged material and ranged from 100 to 190 wt ppm in the HIP'd samples. ${ }^{[4,5]}$ These values were lower than those in the powder and HIP'd steels of the present investigation, where purposefully enhanced oxygen contents in the powders, from storage and handling, were carried through into the HIP'd product to assess the non-metallic inclusions through processing. The grain boundary characterization and grain size in gas-atomized $316 \mathrm{~L}$ austenitic stainless steel powdersAMGA (sieved to 25 to 45 and $<150 \mu \mathrm{m}$ ) and VIGA (sieved to 106 to $150 \mu \mathrm{m}$ ) and after HIP product fabrication - have been presented separately. ${ }^{[17,18]}$ A preliminary comparison of the non-metallic inclusions in the HIP'd products was also made. ${ }^{[17,18]}$

An added challenge is that, in addition to oxidation, the control of tramp elements in steels is becoming more critical to meet the required steel quality as the demand for the use of scrap in steel manufacturing processes has increased significantly. In particular, there is an increased presence of $\mathrm{Cu}$ in scrap due to an increased presence in automotive scrap. ${ }^{[32]} \mathrm{A}$ residual $\mathrm{Cu}$ content in the base composition of $0.2 \mathrm{wt}$ pct can impair the hot workability of the steel. ${ }^{[33]}$ The presence of $\mathrm{Cu}$ in steel scrap can vary in the range between 0.1 and $0.3 \mathrm{wt}$ pct. ${ }^{[3]}$ Practical approaches to remove $\mathrm{Cu}$ from steel scrap have consisted of magnetic separation ${ }^{[33,34]}$ following both shredding ${ }^{[33]}$ or non-shredding. ${ }^{[34]}$ In the former case, it can then be further processed by pyrometallurgy and hydrometallurgy. ${ }^{[33,35]}$ In the latter case, the $\mathrm{Cu}$-rich scrap product can be effectively sorted by hand pickers, sensor-based sorted, sold to specialized sorters, ${ }^{[34]}$ or to copper smelters for $\mathrm{Cu}$ extraction. ${ }^{[34]} \mathrm{In}$ addition, direct sorting of stainless steel from scrap is also plausible. ${ }^{[36]}$

$\mathrm{Cu}$ has an ambivalent character in steels, it may be beneficial or deleterious. Deliberate additions of $\mathrm{Cu}$ are made to wrought steel products to enhance strength $^{[37,38]}$ and to improve the corrosion resistance. ${ }^{[39]}$ Both 17-4 and 15-4 precipitation-hardening $(\mathrm{PH})$ stainless steels are strengthened by $\mathrm{Cu}$-rich precipitates in a martensitic matrix. ${ }^{[40]}$ On the other hand, residual $\mathrm{Cu}$ can cause embrittlement which results from the physical mechanism in neutron-irradiated steel of matrix damage induced by point-defect $\mathrm{Cu}$-rich clusters hardening ${ }^{[41,42]}$ and hardening by copper precipitation. ${ }^{[42,43]}$ In addition, residual $\mathrm{Cu}$ is deleterious to both hot ductility ${ }^{[44]}$ and surface hot shortness. ${ }^{[45]}$ From the point of view of $\mathrm{Cu}$, $\mathrm{Sn}$, and Ni impurities, $\mathrm{Sn}$ was found to enhance the $\mathrm{Cu}$ effect, while Ni had a counteracting action as exemplified by the $\mathrm{Cu}$ equivalent relationship: $\mathrm{Cu}_{\mathrm{eq}}=\mathrm{Cu}+$ $8 \mathrm{Sn}-\mathrm{Ni}^{\left[{ }^{[45]}\right.}$ Note that, the residual levels are generally explicitly included in the materials specifications for aerospace applications. For example, in the IN718 alloy standard, the levels of residual elements (in wt ppm) are extremely low: $3 \mathrm{~Pb}, 0.3 \mathrm{Bi}$, and $3 \mathrm{Se}^{[46]}$ (as cited in Reference Kandasamy et $a l .{ }^{[47]}$ ). Some ASTM $\mathrm{MnMoNiCr}$ grades plate and forging steels used for the manufacture of nuclear reactor pressure vessels have considered maximum $\mathrm{Cu}$ content values of $0.23-0.43^{[48]}$ and $0-20-0.25 \mathrm{wt}$ pet. ${ }^{[49]}$ The ASTM A988/A988M-17 ${ }^{[50]}$ includes $<0.045 \mathrm{P}$ and $<0.03 \mathrm{~S}$ wt pct residuals, and residual $\mathrm{Cu}$ in some of the steel grades. In contrast, the 


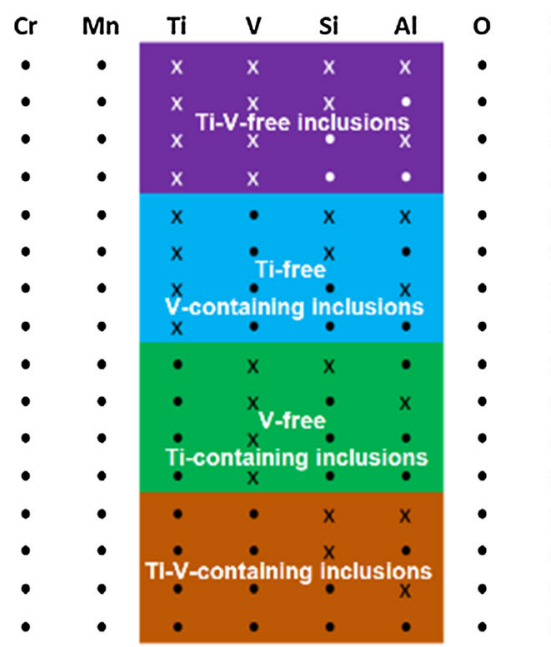

(a)

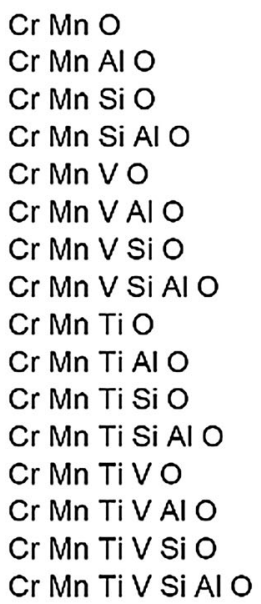

Cr Mn Ti V Si AlO

$\mathrm{Cr}$
$\mathrm{x}$
$\mathrm{x}$
$\mathrm{x}$
$\mathrm{x}$
$\mathrm{x}$
$\mathrm{x}$
$\mathrm{x}$
$\mathrm{x}$
$\mathrm{x}$
$\mathrm{x}$
$\mathrm{x}$
$\mathrm{x}$
$\mathrm{x}$
$\mathrm{x}$
$\mathrm{x}$
$\mathrm{x}$

Fig. 1-Combination of elements in the inclusion classification showing elements being present above the matrix level (•) or not (x). This is depicted in two examples $(a)$ and $(b)$ of combinations of input elements (a) with $\mathrm{Cr}$ and (b) without $\mathrm{Cr}$, and so on for oxysulfides. Note the color code (Color figure online).

specification maximum limit set by a supplier reported residual levels for $316 \mathrm{~L}$ steel includes $<0.025 \mathrm{P},<0.01 \mathrm{~S}$, $<0.5 \mathrm{Cu},<0.1 \mathrm{~N}$, and $<0.1 \mathrm{O}$ wt pet. ${ }^{[51]}$ There are no reports on where any $\mathrm{Cu}$ in the feedstock material is carried over into the powder and HIP products and whether it is associated with inclusions.

In this paper, we investigate the evolution of non-metallic inclusions through processing in $\mathrm{Ti}-\mathrm{V}$ microalloyed $316 \mathrm{~L}$ and $\mathrm{Al}-\mathrm{V}$ microalloyed 17-4PH stainless steels for HIPping applications by means of various techniques: (i) automated SEM/EDS analysis for assessment of non-metallic inclusions and mapping of elements from feedstock to powder to HIP'd product; (ii) XPS analysis for comparison of surface oxides in selected powder precursors, and (iii) HAADF STEM in conjunction with EDX on two HIP'd 316L samples having two residual Ti levels $(<0.005$ and 0.05 wt pct) from AMGA 316L (sieved to $<150 \mu \mathrm{m}$ ) and VIGA 316L (sieved to 106 to $150 \mu \mathrm{m}$ ), respectively. Special attention has been given to trace the variation of $\mathrm{Ti}$ and $\mathrm{V}$ microalloying elements and residual $\mathrm{Cu}$ through processing. Finally, we offer some broader reflections on powder metallurgy of $316 \mathrm{~L}$ stainless steel in light of the evolution of non-metallic inclusions thought processing. We do so, by linking the $\mathrm{Cu}$ residual levels in $316 \mathrm{~L}$ steel, scantly reported in the literature, with our case study to identify gaps leading to potential usage of steel scrap and standardization implications.

\section{EXPERIMENTAL PROCEDURE}

\section{A. Materials}

Feedstock, sieved powders, and HIP'd materials from both nitrogen atomized, AMGA Ti-V microalloyed 316L and VIGA Al-V microalloyed 17-4PH stainless steels as detailed in Tables I and II were supplied by Liberty Speciality Steels, UK. HIPping trials were carried out as follows. Mild steel canisters of $25 \mathrm{~mm}$ diameter and $200 \mathrm{~mm}$ length were filled with powder, vibrated to maximize compact density and vacuum degassed at room temperature. Subsequently, the canisters were sealed by hot crimping the evacuation tube. No gettering agent was used. The HIPping cycle consisted of simultaneous application of temperature at $4.64 \mathrm{~K} / \mathrm{s}\left(5.5^{\circ} \mathrm{C} / \mathrm{min}\right)$ and pressure at $0.009 \mathrm{MPa} / \mathrm{s}$, HIP'd at $1393 \mathrm{~K}\left(1120^{\circ} \mathrm{C}\right)$ and $103 \mathrm{MPa}$ for $4 \mathrm{hrs}$ in an argon atmosphere. After HIPping, the samples were solution annealed for $1 \mathrm{~h}$ at $1323 \mathrm{~K}\left(1050^{\circ} \mathrm{C}\right)$ followed by water quenching. The canning material was removed by mechanical turning.

The chemical composition of the alloy steels investigated through processing as well as the minimum and maximum values as per steel specification are also given in Tables I and II. Note that, the residual levels of $\mathrm{Cu}$ and $\mathrm{Sn}$ are not quoted in the corresponding $316 \mathrm{~L}$ and $17-4 \mathrm{PH}$ steel specifications. The use of Al deoxidation in the $316 \mathrm{~L}$ steel resulted in some variation in residual $\mathrm{Al}$ levels (0.005 to $0.1 \mathrm{wt} \mathrm{pct}$ ), while an $\mathrm{Al}$ microalloying addition led to two levels $<0.05$ and $0.032 \mathrm{wt}$ pct in the $17-4 \mathrm{PH}$ steel. The Ti content in the $316 \mathrm{~L}$ steel varied from $0.13 \mathrm{wt}$ pct in the feedstock to low residual levels of $<0.02 \mathrm{wt}$ pct and $<0.005 \mathrm{wt}$ pct in both AMGA powder and HIP'd product, respectively. While, Ti was partly retained in both the VIGA powder and HIP'd product to $0.046 \mathrm{wt}$ pct and $0.05 \mathrm{wt}$ pct, respectively, Ti microalloying element was at the residual levels $(<0.002$ to $<0.02 \mathrm{wt}$ pct $)$ in the $17-4 \mathrm{PH}$ steel. Deliberate additions of $\mathrm{Nb}$ were made to the 17-4PH steel to act as a chemical carbon scavenger to suppress the formation of chromium carbides. ${ }^{[52]}$ The levels of $\mathrm{Nb}$ microalloying element were residuals $(<0.005$ to $0.013 \mathrm{wt}$ pct $)$ in the $316 \mathrm{~L}$ steel. The microalloying element $\mathrm{V}$ varied between 0.04 and 0.07 
Table III. Summary of Non-metallic Inclusions $\left(\mathrm{mm}^{-2}\right)$ for the 316L Steel Investigated

\begin{tabular}{|c|c|c|c|c|c|}
\hline Non-metallic Inclusion Type & Feedstock & $\begin{array}{c}\text { Powder }<150 \\
\mu \mathrm{m}\end{array}$ & $\begin{array}{l}\text { Powder } \\
106-150 \mu \mathrm{m}\end{array}$ & $\begin{array}{l}\text { HIP'd }<150 \\
\mu \mathrm{m}\end{array}$ & $\begin{array}{l}\text { HIP'd } \\
106-150 \mu \mathrm{m}\end{array}$ \\
\hline $\begin{array}{l}\text { Ti N } \\
\text { Ti N Mn S } \\
\text { Mn Si Al O } \\
\text { Mn Ti Si O } \\
\text { Mn Ti Si Al O } \\
\text { Ti Si Al O }\end{array}$ & $\begin{array}{r}39 \\
178\end{array}$ & $\begin{array}{r}1 \\
17 \\
33\end{array}$ & 11 & & \\
\hline $\begin{array}{l}\text { Cr Mn O } \\
\text { Cr Mn Al O } \\
\text { Cr Mn Si O } \\
\text { Cr Mn Si Al O }\end{array}$ & & & & $\begin{array}{r}6740 \\
0 \\
335 \\
1\end{array}$ & $\begin{array}{l}5 \\
6 \\
7 \\
1\end{array}$ \\
\hline Ti-V-free oxide inclusions & & & & 7076 & 19 \\
\hline $\begin{array}{l}\text { Cr Mn V O } \\
\text { Cr Mn V Al O } \\
\text { Cr Mn V Si O } \\
\text { Cr Mn V Si Al O }\end{array}$ & & & & $\begin{array}{r}150 \\
0 \\
5 \\
1\end{array}$ & $\begin{array}{l}0 \\
0 \\
0 \\
0\end{array}$ \\
\hline Ti-free V-containing oxide inclusions & & & & 156 & 0 \\
\hline $\begin{array}{l}\text { Cr Mn Ti O } \\
\text { Cr Mn Ti Al O } \\
\text { Cr Mn Ti Si O } \\
\text { Cr Mn Ti Si Al O }\end{array}$ & & & & $\begin{array}{l}9 \\
2 \\
0 \\
1\end{array}$ & $\begin{array}{r}1542 \\
868 \\
1378 \\
528\end{array}$ \\
\hline V-free Ti-containing oxide inclusions & & & & 12 & 4316 \\
\hline $\begin{array}{l}\text { Cr Mn Ti V O } \\
\text { Cr Mn Ti V Al O } \\
\text { Cr Mn Ti V Si O } \\
\text { Cr Mn Ti V Si Al O }\end{array}$ & & & & $\begin{array}{r}13 \\
10 \\
2 \\
6\end{array}$ & $\begin{array}{r}310 \\
390 \\
90 \\
113\end{array}$ \\
\hline Ti-V-containing oxide inclusions & & & & 31 & 903 \\
\hline $\begin{array}{l}\mathrm{Cu} \mathrm{O} \\
\mathrm{Cu} \mathrm{Mn} \mathrm{O} \\
\text { Other Oxides }\end{array}$ & & & & $\begin{array}{l}42 \\
31\end{array}$ & $\begin{array}{r}21 \\
2 \\
3523\end{array}$ \\
\hline $\begin{array}{l}\text { Cr Mn S } \\
\text { Cr Mn O S } \\
\text { Cr Mn Al O S } \\
\text { Cr Mn Si O S } \\
\text { Cr Mn Si Al O S }\end{array}$ & & & & $\begin{array}{r}2222 \\
19560 \\
2 \\
1400 \\
1\end{array}$ & $\begin{array}{r}22 \\
1 \\
4 \\
14 \\
2\end{array}$ \\
\hline $\begin{array}{l}\text { Ti-V-Free sulfide and oxysulfide } \\
\text { Inclusions }\end{array}$ & & & & 23185 & 43 \\
\hline $\begin{array}{l}\text { Cr Mn V O S } \\
\text { Cr Mn V Al O S } \\
\text { Cr Mn V Si O S } \\
\text { Cr Mn V Si Al O S }\end{array}$ & & & & $\begin{array}{r}521 \\
1 \\
13 \\
0\end{array}$ & $\begin{array}{l}0 \\
0 \\
0 \\
0\end{array}$ \\
\hline $\begin{array}{l}\text { Ti-Free V-Containing oxysulfide } \\
\text { Inclusions }\end{array}$ & & & & 535 & 0 \\
\hline $\begin{array}{l}\text { Cr Mn Ti O S } \\
\text { Cr Mn Ti Al O S } \\
\text { Cr Mn Ti Si O S } \\
\text { Cr Mn Ti Si Al O S }\end{array}$ & & & & $\begin{array}{r}22 \\
3 \\
10\end{array}$ & $\begin{array}{r}840 \\
510 \\
1030 \\
374\end{array}$ \\
\hline $\begin{array}{l}\text { V-Free Ti-Containing oxysulfide } \\
\text { Inclusions }\end{array}$ & & & & 35 & 2754 \\
\hline Cr Mn Ti V O & & & & 25 & 99 \\
\hline
\end{tabular}


Table III. continued

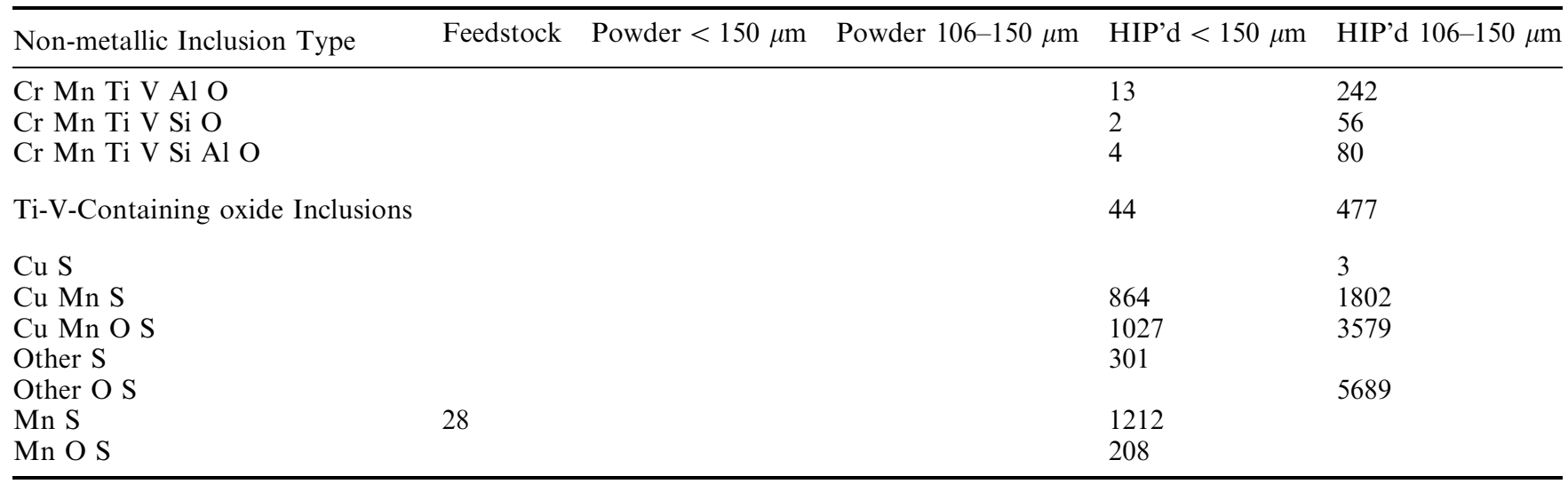

Table IV. Summary of Non-metallic Inclusions $\left(\mathrm{mm}^{-2}\right)$ for the 17-4PH steel investigated

\begin{tabular}{|c|c|c|c|c|}
\hline Non-metallic inclusion type & Feedstock & Powder $<150 \mu \mathrm{m}$ & $\begin{array}{l}\text { HIP'd } 25-45 \mu \mathrm{m} \\
\text { With } \mathrm{Nb}\end{array}$ & $\begin{array}{l}\text { HIP'd } 25-45 \mu \mathrm{m} \\
\text { Without } \mathrm{Nb}\end{array}$ \\
\hline Mn Ti Si Al O & & 10 & & \\
\hline $\begin{array}{l}\mathrm{Cr} \mathrm{Mn} \mathrm{O} \\
\mathrm{Cr} \mathrm{Mn} \mathrm{Al} \mathrm{O} \\
\text { Cr Mn Si O } \\
\text { Cr Mn Si Al O }\end{array}$ & & & $\begin{array}{r}15 \\
463 \\
9 \\
172\end{array}$ & $\begin{array}{r}42 \\
851 \\
1 \\
32\end{array}$ \\
\hline Ti-V-Free oxide Inclusions & & & 659 & 926 \\
\hline $\begin{array}{l}\text { Cr Mn V O } \\
\text { Cr Mn V Al O } \\
\text { Cr Mn V Si O } \\
\text { Cr Mn V Si Al O }\end{array}$ & & & $\begin{array}{r}9 \\
78 \\
2 \\
74\end{array}$ & $\begin{array}{r}3 \\
10 \\
0 \\
1\end{array}$ \\
\hline Ti-Free V-Containing oxide Inclusions & & & 163 & \\
\hline $\begin{array}{l}\text { Cr Mn Ti O } \\
\text { Cr Mn Ti Al O } \\
\text { Cr Mn Ti Si O } \\
\text { Cr Mn Ti Si Al O }\end{array}$ & & & $\begin{array}{l}0 \\
1 \\
0 \\
0\end{array}$ & $\begin{array}{l}0 \\
0 \\
0 \\
0\end{array}$ \\
\hline V-Free Ti-Containing oxide Inclusions & & & 1 & \\
\hline $\begin{array}{l}\text { Cr Mn Ti V O } \\
\text { Cr Mn Ti V Al O } \\
\text { Cr Mn Ti V Si O } \\
\text { Cr Mn Ti V Si Al O }\end{array}$ & & & $\begin{array}{l}0 \\
0 \\
0 \\
0\end{array}$ & $\begin{array}{l}0 \\
0 \\
0 \\
0\end{array}$ \\
\hline Ti-V-Containing oxide Inclusions & & & 0 & \\
\hline $\begin{array}{l}\mathrm{Cu} \mathrm{O} \\
\mathrm{Cu} \mathrm{Mn} \mathrm{O} \\
\text { Other Oxides }\end{array}$ & & & $\begin{array}{r}842 \\
25 \\
581\end{array}$ & $\begin{array}{r}1347 \\
137 \\
1408\end{array}$ \\
\hline $\begin{array}{l}\text { Cr Mn S } \\
\text { Cr Mn O S } \\
\text { Cr Mn Al O S } \\
\text { Cr Mn Si O S } \\
\text { Cr Mn Si Al O S }\end{array}$ & & & $\begin{array}{r}5 \\
12 \\
2 \\
1 \\
4\end{array}$ & $\begin{array}{r}3 \\
39 \\
3 \\
1 \\
3\end{array}$ \\
\hline Ti-V-Free sulphide and oxysulfide Inclusions & & & 24 & 49 \\
\hline $\begin{array}{l}\text { Cr Mn V O S } \\
\text { Cr Mn V Al O S } \\
\text { Cr Mn V Si O S } \\
\text { Cr Mn V Si Al O S }\end{array}$ & & & $\begin{array}{l}9 \\
1 \\
1 \\
3\end{array}$ & $\begin{array}{l}0 \\
1 \\
0 \\
0\end{array}$ \\
\hline
\end{tabular}


Table IV. continued

\begin{tabular}{|c|c|c|c|c|}
\hline Non-metallic inclusion type & Feedstock & Powder $<150 \mu \mathrm{m}$ & $\begin{array}{l}\text { HIP'd } 25-45 \mu \mathrm{m} \\
\text { With Nb }\end{array}$ & $\begin{array}{l}\text { HIP'd } 25-45 \mu \mathrm{m} \\
\text { Without } \mathrm{Nb}\end{array}$ \\
\hline Ti-Free V-Containing oxysulfide Inclusions & & & 14 & 1 \\
\hline Cr Mn Ti O S & & & 0 & 0 \\
\hline $\mathrm{Cr}$ Mn Ti Al O S & & & 0 & 0 \\
\hline Cr Mn Ti Si O S & & & 0 & 0 \\
\hline Cr Mn Ti Si Al O S & & & 0 & 0 \\
\hline V-Free Ti-Containing oxysulfide Inclusions & & & 0 & 0 \\
\hline Cr Mn Ti V O & & & 0 & 0 \\
\hline $\mathrm{Cr} \mathrm{Mn} \mathrm{Ti} \mathrm{V} \mathrm{Al} \mathrm{O}$ & & & 0 & 0 \\
\hline Cr Mn Ti V Si O & & & 0 & 0 \\
\hline Cr Mn Ti V Si Al O & & & 0 & 0 \\
\hline Ti-V-Containing oxide Inclusions & & & 0 & 0 \\
\hline $\mathrm{Cu} \mathrm{S}$ & & & 15 & 112 \\
\hline $\mathrm{Cu} \mathrm{Mn} \mathrm{S}$ & & & 24 & 85 \\
\hline $\mathrm{Cu} \mathrm{Mn} \mathrm{O} \mathrm{S}$ & 1 & & 16 & 71 \\
\hline \multicolumn{5}{|l|}{ Other $\mathrm{S}$} \\
\hline \multicolumn{5}{|l|}{ Other O S } \\
\hline Mn S & 1 & & & \\
\hline $\mathrm{Mn} \mathrm{O} \mathrm{S}$ & & & & \\
\hline
\end{tabular}

Table V. Number Density $\left(\mathrm{mm}^{-2}\right)$ of Cu-Containing Inclusions from the HIP'd 316L Steel in Table III

\begin{tabular}{|c|c|c|c|c|c|c|c|c|}
\hline \multirow[b]{2}{*}{ Size $(\mu \mathrm{m})$} & \multicolumn{3}{|c|}{ HIP'd $<150 \mu \mathrm{m}$} & \multicolumn{5}{|c|}{ HIP'd 106-150 $\mu \mathrm{m}$} \\
\hline & $\mathrm{Cu} \mathrm{Mn} \mathrm{O}$ & $\mathrm{Cu} \mathrm{Mn} \mathrm{S}$ & $\mathrm{Cu} \mathrm{Mn} \mathrm{O} \mathrm{S}$ & $\mathrm{CuO}$ & $\mathrm{Cu} \mathrm{Mn} \mathrm{O}$ & $\mathrm{Cu} \mathrm{S}$ & $\mathrm{Cu} \mathrm{Mn} \mathrm{S}$ & $\mathrm{Cu} \mathrm{Mn} \mathrm{O} \mathrm{S}$ \\
\hline $0-1$ & 42 & 863 & 1019 & 17 & 2 & 3 & 1773 & 3482 \\
\hline $1-2$ & & 0 & 8 & 4 & & & 29 & 86 \\
\hline $2-3$ & & 1 & 0 & & & & & 10 \\
\hline $3-4$ & & & & & & & & 1 \\
\hline
\end{tabular}

Table VI. Number Density $\left(\mathrm{mm}^{-2}\right)$ of Cu-Containing Inclusions from the HIP'd 17-4PH $25-45 \mu \mathrm{m}$ Sample in Table IV

\begin{tabular}{|c|c|c|c|c|c|c|c|c|c|c|}
\hline \multirow[b]{2}{*}{ Size $(\mu \mathrm{m})$} & \multicolumn{5}{|c|}{ HIP'd $<150 \mu \mathrm{m}$} & \multicolumn{5}{|c|}{ HIP'd 106-150 $\mu \mathrm{m}$} \\
\hline & $\mathrm{Cu} \mathrm{O}$ & $\mathrm{Cu} \mathrm{Mn} \mathrm{O}$ & $\mathrm{Cu} \mathrm{S}$ & $\mathrm{Cu} \mathrm{Mn} \mathrm{S}$ & $\mathrm{Cu} \mathrm{Mn} \mathrm{O} \mathrm{S}$ & $\mathrm{Cu} \mathrm{O}$ & $\mathrm{Cu} \mathrm{Mn} \mathrm{O}$ & $\mathrm{Cu} \mathrm{S}$ & $\mathrm{Cu} \mathrm{Mn} \mathrm{S}$ & $\mathrm{Cu} \mathrm{Mn} \mathrm{O} \mathrm{S}$ \\
\hline$\overline{0-1}$ & 839 & 22 & 15 & 24 & 14 & 1343 & 132 & 112 & 84 & 64 \\
\hline $1-2$ & 3 & 3 & & & 2 & 4 & 5 & & 1 & 6 \\
\hline $2-3$ & & & & & & & & & & 1 \\
\hline
\end{tabular}

wt pet in the $316 \mathrm{~L}$ steel and $0.08 \mathrm{wt}$ pct $\mathrm{V}$ in the $17-4 \mathrm{PH}$ steel.

The $\mathrm{C}$ and $\mathrm{S}$ contents of the samples were determined using an Eltra ${ }^{\mathrm{TM}}$ CS-2000 carbon/sulfur analyzer equipped with a high-frequency induction furnace for the air-melted powder and by $\mathrm{LECO}^{\mathrm{TM}}$ for the VIGA powder. The $\mathrm{N}$ and $\mathrm{O}$ contents of the samples were analyzed by $\mathrm{LECO}^{\mathrm{TM}}$. The other elements were analyzed by inductively coupled plasma optical emission spectrometry (ICP-OES).

\section{B. Characterization Techniques}

\section{SEM}

SEM backscattered electron imaging (BSEI) and EDS were carried out using a Versa 3D dual-beam SEM operating at $10 \mathrm{kV}$. Elemental analyses and mappings were processed using the Aztec OI software feature that integrates EDS analysis software with an XMax 80 SDD (Silicon Drift Detector) detector. BSEIs in conjunction with EDS were used to quantify the inclusion size 


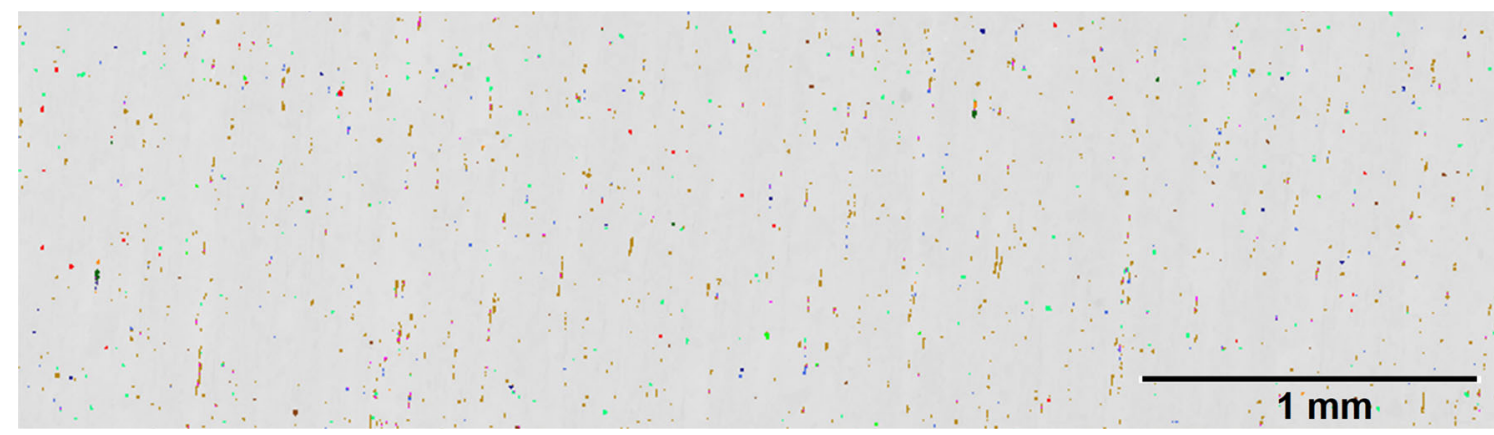

Fig. 2-Inclusion map for the $316 \mathrm{~L}$ steel feedstock.

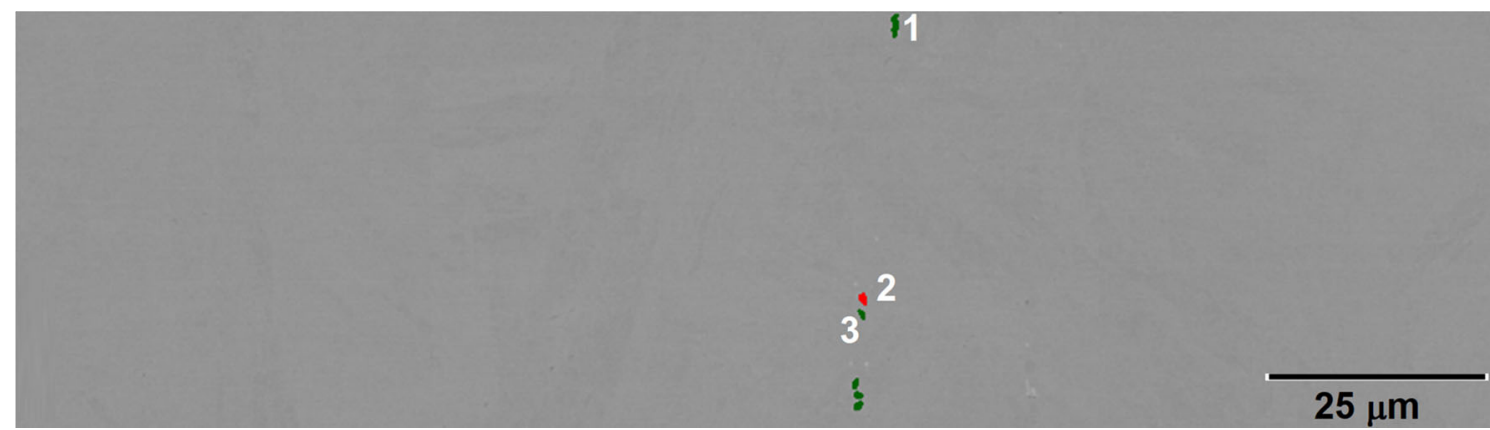

Fig. 3-Phase analysis for the 17-4PH steel feedstock showing Cr-rich (green 1 and 3) and Cr-Nb-rich (red 2) phases (Color figure online).

Table VII. EDS Analysis (Weight Percent) from the Phases in Fig. 3

\begin{tabular}{cccccccr}
\hline Phase & $\mathrm{Fe}$ & $\mathrm{Cr}$ & $\mathrm{Ni}$ & $\mathrm{Cu}$ & $\mathrm{Nb}$ & $\mathrm{Si}$ & $\mathrm{C}$ \\
\hline $\mathbf{1}$ & $60.3 \pm 0.5$ & $34.9 \pm 0.4$ & $2.8 \pm 0.3$ & $1.9 \pm 0.3$ & & & \\
$\mathbf{2}$ & $58.8 \pm 0.5$ & $35.4 \pm 0.4$ & $2.3 \pm 0.3$ & $1.7 \pm 0.3$ & $1.3 \pm 0.3$ & $0.3 \pm 0.1$ & $3.1 \pm 0.6$ \\
$\mathbf{3}$ & $58.1 \pm 0.6$ & $35.7 \pm 0.4$ & $1.9 \pm 0.3$ & $1.2 \pm 0.3$ & & & \\
\hline
\end{tabular}

(maximum dimension), number density and type on feedstock, and HIP'd product both on polished cross-sections and on polished powders, which required cold mounting and Au sputtering in an Agar auto sputter coater, using a setting of $40 \mathrm{~mA}$, for 30 seconds. Preliminary EDS analysis of inclusions has confirmed the presence of elements to be included in our choice of classification to be input hierarchically in descending elemental content as established in the Aztec OI software. First, inclusions were categorized in two groups: with and without $\mathrm{Cu}$. Second and for each of the two groups, inclusions were divided into four groups (oxysulfides, oxides, sulfides, and without both oxygen and sulfur) to analyze combinations of $\mathrm{Cr}$ and/or $\mathrm{Mn}$ with oxysulfides, oxides, sulfides, and without both oxygen and sulfur for combinations of 4-element subset (Ti V Si Al). In summary, combinations of 4-element subsets (Cr Mn O S) (Ti V Si Al) of an 8-element set were determined as illustrated in Figure 1. Other particular elements present in the analysis of a feature are also included in the EDS spectrum for later classification, for example, elements arising from cross-contamination and other residuals. An exemplification of nitrogen containing inclusions has been classified for combinations of $(\mathrm{Mn} \mathrm{Ti})$ or $\mathrm{Ti}$ with and without $\mathrm{V}$ subclasses with (N O S), (N S), and (O S).

\section{X-ray photoelectron spectroscopy (XPS)}

X-ray photoelectron spectroscopy (XPS) data were acquired using a Kratos Axis Ultra DLD spectrometer. The powders were mounted on to a sample bar using electrically conductive carbon tape and loaded in to the vacuum system. After pumping down, the samples were transferred to the analysis chamber (base pressure $1 \times$ $10^{-10}$ mbar) and illuminated with an $\mathrm{A} 1 \mathrm{~K} \alpha \mathrm{X}$-ray source $(\mathrm{h} v=1486.7 \mathrm{eV})$. The photoelectrons were collected in a hemispherical analyzer from an area of $300 \mu m \times 700$ $\mu \mathrm{m}$ on the sample surface. The binding energy scale of the spectrometer was calibrated using the $\mathrm{Ag} 3 \mathrm{~d}$ and Fermi edge positions acquired from a clean polycrystalline Ag surface prior to the experiments. Survey spectra were recorded with a pass energy of $160 \mathrm{eV}$ (resolution approximately $2 \mathrm{eV}$ ), while core-level spectra were recorded at a pass energy of $20 \mathrm{eV}$ (resolution approximately $0.4 \mathrm{eV}$ ). XPS data were acquired from the samples at normal emission in the as-received 


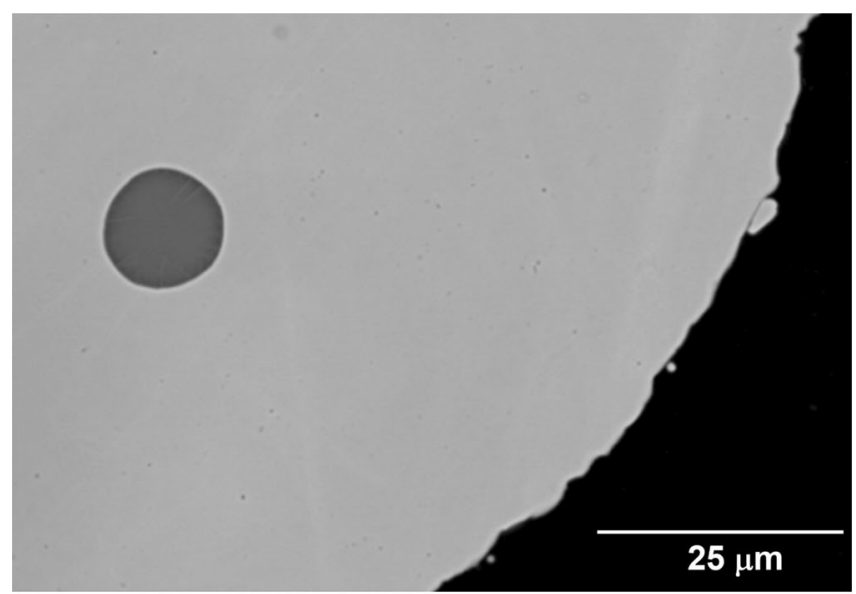

(a)

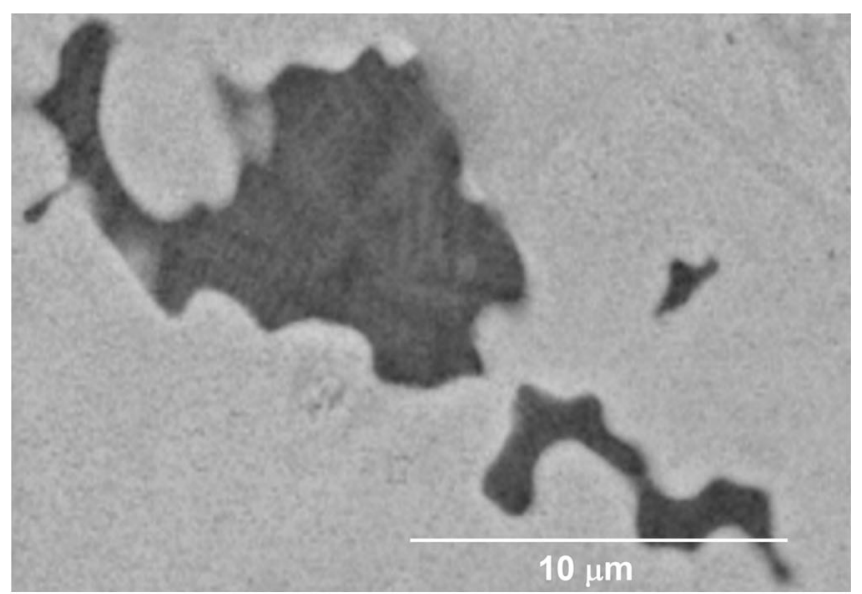

(b)

Fig. 4 -Inclusion analysis for the AMGA 316L powder $<150 \mu$ m showing $(a)$ globular and $(b)$ dendritic morphologies.

Table VIII. EDS Analysis (Weight Percent) from the Inclusions in Fig. 4

\begin{tabular}{|c|c|c|c|c|c|c|c|c|c|}
\hline & $\mathrm{Mn}$ & $\mathrm{O}$ & $\mathrm{Cr}$ & $\mathrm{Si}$ & $\mathrm{C}$ & $\mathrm{Ti}$ & $\mathrm{Fe}$ & $\mathrm{Al}$ & $\mathrm{Ni}$ \\
\hline (a) & $23.2 \pm 0.6$ & $23.2 \pm 1.0$ & $13.9 \pm 0.4$ & $11.5 \pm 0.3$ & $9.3 \pm 1.4$ & $8.5 \pm 0.3$ & $7.6 \pm 0.4$ & $1.5 \pm 0.2$ & $1.3 \pm 0.2$ \\
\hline (b) & $20.3 \pm 0.6$ & $23.4 \pm 1.1$ & $11.1 \pm 0.4$ & $7.6 \pm 0.2$ & $12.7 \pm 1.3$ & $11.6 \pm 0.3$ & $9.0 \pm 0.4$ & $1.1 \pm 0.1$ & $1.4 \pm 0.2$ \\
\hline
\end{tabular}

condition and following $\mathrm{Ar}^{+}$sputtering using an incident ion beam energy of $4 \mathrm{keV}$ for 15 minutes with an angle between the sample surface and the ion beam of $45^{\circ}$. The resulting spectra were analyzed using the CasaXPS package ${ }^{[53]}$ (version 2.3.19), using mixed Gaussian-Lorentzian (Voigt) lineshapes, asymmetry parameters where appropriate, and Shirley backgrounds.

\section{TEM}

TEM samples from the AMGA HIP'd 316L $<150 \mu \mathrm{m}$ and VIGA HIP'd 106 to $150 \mu \mathrm{m}$ products were prepared using focused ion beam (FIB) lift-out techniques in a Scios dual-beam FIB-SEM and were examined in an FEI Talos F200X S/TEM equipped with a Super X 4-quadrant X-ray detector, operating at $200 \mathrm{kV}$. TEM samples were attached to a $\mathrm{Cu}$ FIB TEM grid.

\section{RESULTS}

BSEI and EDS identified single and multi-phase inclusions, for both feedstock and HIP'd 316L steel conditions, while discrete phase inclusions were identified for the $316 \mathrm{~L}$ powders. BSEI and EDS for the feedstock, powder, and HIP'd 17-4PH steel conditions identified not only non-metallic inclusions in all three samples, but also oxygen-free phases. Non-metallic inclusions for the 17-4 PH steel were present in much lower amounts than the corresponding feedstock, powder, and HIP'd 316L steel conditions. They were also found as single and multi-phase inclusions, for both feedstock and HIP conditions, while discrete single-phase inclusions were identified for the powders.

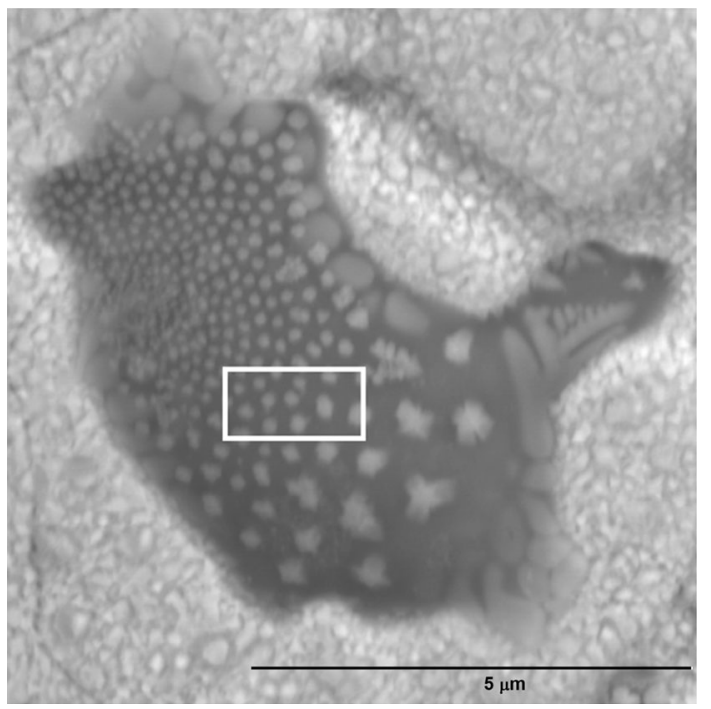

Fig. 5-Mn-Ti-(V)-Si-Al-containing oxide particulate on the powder surface from the VIGA $316 \mathrm{~L} 106$ to $150 \mu \mathrm{m}$ sample.

Histograms of the inclusion number density through processing from the feedstock to powder to the HIP'd product are plotted in supplementary Figure S-1, for the $316 \mathrm{~L}$ steel, and in supplementary Figure S-2, for the 17-4PH steel (refer to electronic supplementary material). The variation of the number density of inclusion types through processing for the two steels are summarized in Tables III and IV. The number density of the $\mathrm{Cu}$-containing inclusions for all the three HIP'd samples are summarized in Tables $\mathrm{V}$ and VI. 
An automated BSE image of the inclusions for the 316 L steel feedstock is shown in Figure 2. The main phases identified in the $316 \mathrm{~L}$ feedstock were $\mathrm{Al}_{2} \mathrm{O}_{3}$, $\mathrm{MnS}$, and $(\mathrm{Ti}, \mathrm{V})(\mathrm{C}, \mathrm{N})$ as single-phase inclusions or as part of multi-phase inclusions which included the following four main combinatory types: $\mathrm{Al}_{2} \mathrm{O}_{3} / \mathrm{MnS}$; $(\mathrm{Ti}, \mathrm{V})(\mathrm{C}, \mathrm{N}) / \mathrm{Al}_{2} \mathrm{O}_{3} ;(\mathrm{Ti}, \mathrm{V})(\mathrm{C}, \mathrm{N}) / \mathrm{MnS}$; and $(\mathrm{Ti}, \mathrm{V})(\mathrm{C}, \mathrm{N}) /$ $\mathrm{Al}_{2} \mathrm{O}_{3} / \mathrm{MnS}$.

An automated BSE image for the 17-4PH steel feedstock is shown in Figure 3. Oxygen-free phases were found to be darker with respect to the steel matrix in the 17-4PH steel feedstock. Those darker segregated second phases consisted of Cr-rich, low-Cu with or without (more frequent) $\mathrm{Nb}$. Three examples from Figure 3 are given in Table VII.

\section{B. 316L and 17-4PH Stainless Steel Powders}

The majority of non-metallic inclusions in the $316 \mathrm{~L}$ powder were present as individual, single-phase particles of largely globular morphology (Figure 4(a) and Table VIII), but isolated inclusions of dendritic morphology were also observed (Figure 4(b) and Table VIII). Those are (i) predominantly of a Mn-Ti-Si-Al-containing oxide type followed by Mn-Ti-Si-containing oxides for the $316 \mathrm{~L}<150 \mu \mathrm{m}$ powder (supplementary Figure S-1(b)) and (ii) predominantly of a Ti-Si-Al-containing oxide type followed by other oxides (such as Mn-Ti-Al-containing oxides and Ca-containing oxides), and then in the same ranking order by $\mathrm{Mn}$-Ti-Si-containing oxides and Mn-Ti-Si-Al-containing oxides for the 316L 106 to 150 $\mu \mathrm{m}$ powder (supplementary Figure S-1(c)). Figure 5 shows a coarse Mn-Ti-(V)-Si-Al-containing oxide particulate on the surface of a VIGA powder 316L 106 to $150 \mu \mathrm{m}$ sample. Its EDS analysis is given in Table IX.

The main inclusion type for the VIGA $17-4 \mathrm{PH}<150$ $\mu \mathrm{m}$ sample was found to be the same as that for the AMGA $316 \mathrm{~L}<150 \mu \mathrm{m}$ sample: Mn-Ti-Si-Al-containing oxide inclusions (supplementary Figures S-2(b) c.f. S-1(b)). The chemical composition values for the $\mathrm{Mn}$-Ti-Si-Al-containing oxide inclusions case were in the range (8.46 to 21.20$) \mathrm{Cr}-(2.60$ to 18.04$) \mathrm{Mn}-(3.26$ to $17.00) \mathrm{Si}-(0.38$ to 6.30$) \mathrm{Al}-(0.34$ to 3.61$) \mathrm{Ti}$ (wt pet).

Survey spectra were acquired from the three powders in the as-received condition and, as shown in supplementary Figure S-3, revealed the presence of many different elements within the typical sampling depth of XPS (5 to $10 \mathrm{~nm}$ ). Table $X$ shows the atomic concentrations of the different elements detected after analysis of core-level spectra which were subsequently acquired (supplementary Figures S-4 to S-11). Table XI shows the relative amounts of $\mathrm{Fe}, \mathrm{FeO}$, and $\mathrm{Fe}_{2} \mathrm{O}_{3}$ in the near-surface region. Table XII summarizes the metallic elements and compounds for the three powders.

\section{HIP'd 316L and 17-4PH Stainless Steels}

Inclusion maps, examples of specific inclusions and their EDS analysis from the HIP'd samples consolidated from the $316 \mathrm{~L}<150 \mu \mathrm{m}$ powder are shown in Figure 6 
Table X. Total Elemental Compositions (Atomic Percent) of the Three Powders Studied in this Investigation, Before and After $\mathrm{Ar}^{+}$Sputtering at $4 \mathrm{keV}$

\begin{tabular}{llccccccccccccccccc}
\hline Sample & State & $\mathrm{C}$ & $\mathrm{O}$ & $\mathrm{P}$ & $\mathrm{Cr}$ & $\mathrm{Ni}$ & $\mathrm{Si}$ & $\mathrm{Mn}$ & $\mathrm{Ti}$ & $\mathrm{Fe}$ & $\mathrm{Mo}$ & $\mathrm{Cu}$ & $\mathrm{Sn}$ & $\mathrm{V}$ & $\mathrm{Nb}$ & $\mathrm{N}$ & $\mathrm{Na}$ \\
\hline 316L 106-150 $\mu \mathrm{m}$ & as-received & 30.0 & 52.7 & 0.0 & 2.0 & 0.9 & 2.8 & 4.2 & 1.1 & 6.0 & 0.4 & 0.0 & 0.0 & 0.0 & 0.0 & 0.0 & 0.0 \\
316L 106-150 $\mu \mathrm{m}$ & sputtered & 27.6 & 50.5 & 0.0 & 2.9 & 1.4 & 2.7 & 4.6 & 1.3 & 8.6 & 0.5 & 0.0 & 0.0 & 0.0 & 0.0 & 0.0 & 0.0 \\
316L 15-45 $\mu \mathrm{m}$ & as-received & 28.6 & 53.7 & 0.0 & 2.0 & 0.7 & 6.3 & 3.2 & 0.0 & 5.2 & 0.4 & 0.0 & 0.0 & 0.0 & 0.0 & 0.0 & 0.0 \\
316L 15-45 $\mu \mathrm{m}$ & sputtered & 26.8 & 52.5 & 0.0 & 2.7 & 0.7 & 5.9 & 3.6 & 0.0 & 7.4 & 0.4 & 0.0 & 0.0 & 0.0 & 0.0 & 0.0 & 0.0 \\
17-4PH 106-150 $\mu \mathrm{m}$ & as-received & 24.0 & 50.5 & 3.0 & 1.0 & 0.1 & 3.4 & 0.0 & 0.0 & 9.7 & 0.0 & 6.6 & 0.1 & 0.0 & 0.7 & 0.5 & 0.5 \\
17-4PH 106-150 $\mu \mathrm{m}$ & sputtered & 18.9 & 26.9 & 2.1 & 5.6 & 1.9 & 3.6 & 0.0 & 0.0 & 33.9 & 0.0 & 5.2 & 0.1 & 0.0 & 0.7 & 1.1 & 0.0 \\
\hline
\end{tabular}

Table XI. Relative Abundancies of $\mathrm{Fe}(0), \mathrm{Fe}_{2} \mathrm{O}_{3}$, and $\mathrm{FeO}$ Observed in the Three Steel Powders, Measured in the As-Received Condition and After $\mathrm{Ar}^{+}$Sputtering at $4 \mathrm{keV}$

\begin{tabular}{|c|c|c|c|c|}
\hline Sample & State & Metallic $\mathrm{Fe}(0)$ & $\mathrm{Fe}_{2} \mathrm{O}_{3}$ & $\mathrm{FeO}$ \\
\hline $316 \mathrm{~L} 106-150 \mu \mathrm{m}$ & as-received & 13.5 & 63.7 & 22.9 \\
\hline $316 \mathrm{~L} 106-150 \mu \mathrm{m}$ & sputtered & 8.9 & 14.6 & 76.5 \\
\hline $316 \mathrm{~L} 15-45 \mu \mathrm{m}$ & as-received & 7.0 & 93.0 & 0.0 \\
\hline $316 \mathrm{~L} 15-45 \mu \mathrm{m}$ & sputtered & 5.3 & 34.3 & 60.4 \\
\hline $17-4 \mathrm{PH} 106-150 \mu \mathrm{m}$ & as-received & 8.1 & 27.3 & 64.7 \\
\hline $17-4 \mathrm{PH} 106-150 \mu \mathrm{m}$ & sputtered & 80.9 & 0.0 & 19.1 \\
\hline
\end{tabular}

and Table XIII and from the 316L 106 to $150 \mu \mathrm{m}$ powder are shown in Figure 7 and Table XIV. BSEI and EDS analyses of a coarse, complex, two-phase inclusion are shown in Figure 8 and Table XV for the former case and in Figure 9 for the latter case. AMGA HIP'd 316L $<150 \mu \mathrm{m}$ and VIGA HIP'd 106 to $150 \mu \mathrm{m}$ samples were also characterized by TEM to confirm the presence or absence of Ti-containing precipitates. HAADF-STEM images and the corresponding EDAX elemental maps are shown in Figures 10 and 11.

An automated BSE image for the HIP'd 17-4PH 25 to $45 \mu \mathrm{m}$ sample is shown in Figure 12. Oxygen-free phases were found to have a white contrast phase in BSEI, with the majority of the cases being Nb-rich (red), for example, $37.8 \mathrm{Nb}-27.7 \mathrm{Cr}-4.9 \mathrm{~N}-2.0 \mathrm{~V}-1.2 \mathrm{Cu}$, but with some examples being $\mathrm{Cu}$-rich (blue) $62.5 \mathrm{Cu}-$ rich, Figure 12, (as per atomic number Z-contrast 92.906 $\mathrm{Nb}, 63.546 \mathrm{Cu}$, and $55.845 \mathrm{Fe}$ molar weight). Histograms of the number density of those white contrast phases are plotted in supplementary Figure S-13. It can be seen that the majority of the white contrast phase was $\left.\mathrm{Nb} \mathrm{V} \mathrm{Cr} \mathrm{Cu} \mathrm{(N)} \mathrm{(11944} \mathrm{mm}^{-2}\right)$, followed in decreasing order by $\mathrm{Nb} \mathrm{Cr}(\mathrm{Cu} \mathrm{V} \mathrm{N})\left(414 \mathrm{~mm}^{-2}\right)$; V-free, low $\mathrm{Cu}$ (0.6 to $3.6 \mathrm{wt}$ pct) $\left(377 \mathrm{~mm}^{-2}\right)$, and $\mathrm{Cu}$-rich (4 to $45.6 \mathrm{wt}$ pct) $\left(131 \mathrm{~mm}^{-2}\right)$. It can also be seen that oxidation did not generally occur, with the exception of the some $\mathrm{Nb}-\mathrm{Cr}$-Mn-containing $\left(103 \mathrm{~mm}^{-2}\right)$ and $\mathrm{Cu}$-rich (5 out of $131 \mathrm{~mm}^{-2}$ ) phases (Table XVI).

\section{DISCUSSION}

\section{A. 316L and 17-4PH Stainless Steel Feedstocks}

The multi-phase inclusions identified for $316 \mathrm{~L}$ feedstock are consistent with high melting point $\mathrm{Al}_{2} \mathrm{O}_{3}$ inclusions acting as nucleation sites for $\mathrm{MnS}$ and
$(\mathrm{Ti}, \mathrm{V})(\mathrm{C}, \mathrm{N})$ inclusions and also $\mathrm{MnS}$ inclusions precipitating on the pre-existing $\mathrm{Al}_{2} \mathrm{O}_{3}$ and/or $(\mathrm{Ti}, \mathrm{V})(\mathrm{C}, \mathrm{N}){ }^{\left[{ }^{[4]}\right]}$ The 17-4PH steel feedstock had relatively low levels of 0.0009S-0.0010O-0.030N (wt pct) (Table II) and had a significantly lower number density of inclusions than the 316L feedstock (Figure 3 c.f. Figure 2 and supplementary Figure S-2(a) c.f. Figure S-1(a)).

\section{B. 316L and 17-4PH Stainless Steel Powders}

Inclusions in the $316 \mathrm{~L}$ powder were predominantly Mn-Ti-Si-Al-containing oxides inside the powder particles (Figure 4 and Table VIII), however, they were also observed on the surface of powder particles (Figure 5 and Table IX). Some examples of exogenous Ca-containing oxide inclusions were seen in the $316 \mathrm{~L}$ steel, which could have arisen from trapped slag or refractories in the melt, such as calcium aluminates and silica, rather than cross-contamination of powder precursors during powder production, handling, and processing. ${ }^{22,55,56]}$

Hryha et al. ${ }^{[16]}$ reported nano-sized Cr-Mn-Si-rich surface oxide particulates in $316 \mathrm{~L}$ to be very fine $(\sim 10$ $\mathrm{nm}$ ) in the as-atomized condition and relatively coarse, up to $200 \mathrm{~nm}$, in powder recycled after AM by EBM and LS processing from powder precursors produced by VIGA. Experimental observations in another study ${ }^{[57]}$ showed evidence that a mixture of $\mathrm{SiO}_{2}$ and $\mathrm{MnCr}_{2} \mathrm{O}_{4}$ particles can form on the surface of gas-atomized $316 \mathrm{~L}$ in powder recycling after AM by laser powder bed fusion processing. Coarse $\mathrm{Mn}$-Ti-Si-Al-containing oxide inclusions in the $316 \mathrm{~L}$ powder of the present investigation were found to be micron-sized and non-Cr-rich (see EDS analysis in Figures 4 and 5), indicating that $\mathrm{Cr}$ enrichment in the abovementioned particles of up to 200 $\mathrm{nm}$ in size could have occurred as a result of powder recycling after AM by EBM and LS processing. 


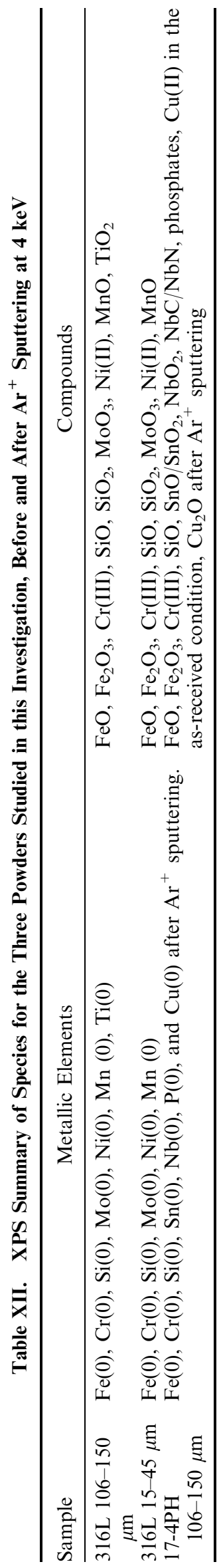

Similar to the feedstock compared above, the number density of inclusions for the VIGA $17-4 \mathrm{PH}<150 \mu \mathrm{m}$ sample was also significantly lower than that for the AMGA 316L $<150 \mu \mathrm{m}$ sample (supplementary Figure S-2(b) c.f. Figures S-1(b) and (c)), despite its relatively high oxygen level $0.0010 \mathrm{~S}-0.0318 \mathrm{O}-0.0351 \mathrm{~N}$ (wt pct) (Table II), suggesting that in the VIGA 17-4PH $<150 \mu \mathrm{m}$ sample, oxygen was mainly present in the form of surface oxides as the feedstock had only $10 \mathrm{wt}$ ppm O.

From a comparative study of non-metallic inclusions in $17-4 \mathrm{PH}$ powder and after being additively manufactured by selective laser melting, Sun et al. ${ }^{[19]}$ reported the chemical composition (in wt pct) by TEM-EDXS in powder to be $14.2 \mathrm{Cr}-21.3 \mathrm{Mn}-9.7 \mathrm{Al}-22.7 \mathrm{Si}-32.1 \mathrm{O}$ for a large micron-sized inclusion. In the same study, Sun et al ${ }^{[19]}$ also reported that the ASTM A564 or AMS 5643 for 17-4PH specification do not include microalloying elements such as $\mathrm{Ti}, \mathrm{Al}$, and $\mathrm{V}$, and therefore pointed out to an exogenous origin for those Al-containing inclusions, possibly arising from melt-crucible or melt-nozzle interactions during gas atomization. In contrast, the VIGA 17-4PH steel in the present investigation was Al- and V-doped (not Ti-doped) and had a lower number density of inclusions in the powder (supplementary Figure S-2(b)) than that reported in the work by Sun et al. ${ }^{[19]}$ in which the $17-4 \mathrm{PH}$ steel powder had an increased $0.0030 \mathrm{~S}-0.046 \mathrm{O}-0.11 \mathrm{~N}$ content (wt pct).

\section{XPS Analysis}

From the survey spectra in supplementary Figure S-3 and Table $\mathrm{X}$, it is immediately clear from these data that $\mathrm{Cu}$ is only present near the surface of the 17-4PH 106 to $150 \mu \mathrm{m}$ powder, with the two $316 \mathrm{~L}$ powders not exhibiting the characteristic $\mathrm{Cu} 2 p_{3 / 2}$ component in the region of $932 \mathrm{eV}$, as shown in supplementary Figures S-3 and $\mathrm{S}-4$.

The high-resolution spectra acquired from the $\mathrm{Fe} 2 p_{3 /}$ 2 region of each sample before and after $\mathrm{Ar}^{+}$sputtering are shown in supplementary Figure S-5, with the work of Biesinger and co-workers used as the basis for analysis of these data. ${ }^{[58]}$ As detailed in Table X, the total $\mathrm{Fe}$ content increased in all three samples following sputtering, indicating that surface contamination and other overlying material had been removed during this process. While the change was discernible in both $316 \mathrm{~L}$ powders, the increase in total $\mathrm{Fe}$ observed was significantly greater in the $17-4 \mathrm{PH}$ powder, indicating that $\mathrm{Fe}$ and the associated oxides are closer to the surface of this particular powder and hence more exposed to the ion beam.

Analysis of the $\mathrm{Fe} 2 p_{3 / 2}$ core-level spectra revealed the presence of metallic $\mathrm{Fe}, \mathrm{FeO}$, and $\mathrm{Fe}_{2} \mathrm{O}_{3}$ in the near-surface region. Table XI shows that the relative amount of $\mathrm{Fe}_{2} \mathrm{O}_{3}$ is reduced during sputtering in all three cases, suggesting that it is located at the surface. Interestingly, sputtering the $17-4 \mathrm{PH}$ sample also removes $\mathrm{FeO}$ and reveals more metallic $\mathrm{Fe}(0)$, whereas both $316 \mathrm{~L}$ powders see an increase in the relative 

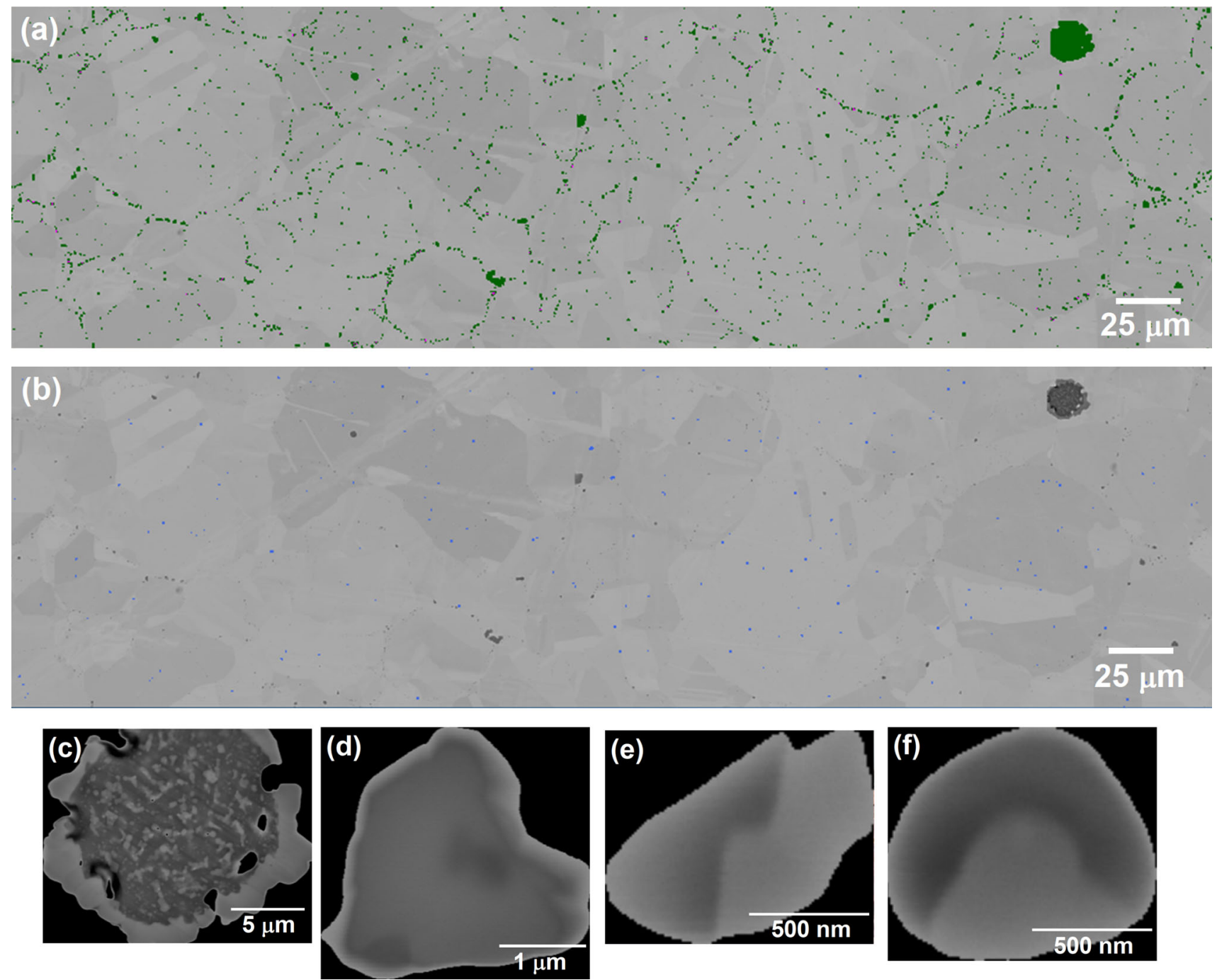

Fig. 6-Inclusion maps for the HIP'd 316L $<150 \mu \mathrm{m}$ sample showing (a) Cr-containing inclusions; (b) Cu-containing inclusions; and examples of specific inclusions: $(c)$ a Cr-Mn-Ti-V-Si-Al- $(\mathrm{Ca})$-containing oxide inclusion; $(d)$ a $\mathrm{Cr}-\mathrm{Mn}$-Ti-V-Si-containing oxide inclusion; and $(e)$ and $(f) \mathrm{Cu}$ Mn O S inclusions.

amount of $\mathrm{FeO}$ after sputtering. Again, this indicates a thicker $\mathrm{Fe}_{2} \mathrm{O}_{3}$ layer on the surface of the 316L powders.

The base composition of all three powders contains detectable amounts of Mo, $1.99 \mathrm{wt}$ pet in 316L 106 to $150 \mu \mathrm{m}, 2.32 \mathrm{wt}$ pct in $316 \mathrm{~L} 15$ to $45 \mu \mathrm{m}$ and $0.12 \mathrm{wt}$ pct in 17-4PH. Hryha et al. ${ }^{[16]}$ and Leicht et al. ${ }^{[59]}$ proposed that Mo and Ni are both found in the metallic state in $316 \mathrm{~L}$ powders, and to test this hypothesis high-resolution spectra of the Mo $3 d$ and Ni $2 p$ regions were acquired from the $316 \mathrm{~L}$ powders as shown in supplementary Figure S-6. Note that the intensity from the as-received $17-4 \mathrm{PH}$ powder in the Ni $2 p$ region was too low to accurately fit, and there was no evidence of the presence of Mo whatsoever. However, the data from the $316 \mathrm{~L}$ powders were of sufficient quality to enable observation of both metallic and oxidized components in both elements. In the Mo $3 d$ region, the metallic $\mathrm{Mo}(0)$ components were observed at 227.3 and $230.5 \mathrm{eV}$ in the $316 \mathrm{~L} 106$ to $150 \mu \mathrm{m}$ powder, with corresponding peaks recorded at 227.8 and $231.0 \mathrm{eV}$ in the $316 \mathrm{~L} 15$ to 


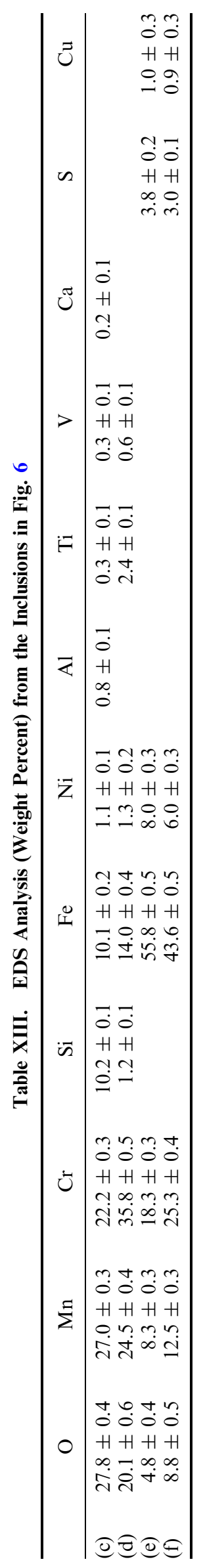

$45 \mu \mathrm{m}$ case. An additional doublet at 232.2/232.3 and $235.3 / 235.4 \mathrm{eV}$ was required in order to fully replicate the experimental data, corresponding to $\mathrm{MoO}_{3}$ in a roughly equal quantity compared to $\operatorname{Mo}(0)$. This suggests a layer of $\mathrm{MoO}_{3}$ on top of the $\mathrm{Mo}(0)$. A similar situation was observed in the $\mathrm{Ni} 2 p_{3 / 2}$ region, where metallic $\mathrm{Ni}(0)$ presented a single component at 852.7 / $852.8 \mathrm{eV}$ and a series of peaks corresponding to $\mathrm{Ni}(\mathrm{II})$ environments from the work of Biesinger ${ }^{[58]}$ were required to replicate the data.

Due to the $\mathrm{Ni}$ and $\mathrm{Cu}$ contents of the 17-4PH powder, it was not possible to accurately fit the Mn $2 p$ spectrum from this sample. However, $\mathrm{MnO}$ was observed in both $316 \mathrm{~L}$ powders, while $\mathrm{NbO}_{2}$ and $\mathrm{NbC} / \mathrm{NbN}$ were detected in the $\mathrm{Nb} 3 d$ region of the $17-4 \mathrm{PH}$ sample, as shown in supplementary Figure S-7. The observation of $\mathrm{Mn}$ oxides is again similar to the results of Leicht et al. ${ }^{[59]}$ and Hryha et al..$^{[16]}$

Potentially important impurities including Ti, Sn, P, and $\mathrm{Cu}$, which may influence various properties of the steel, were detected using ICP and/or XPS. A Ti content of $0.046 \mathrm{wt}$ pct was measured in ICP for the 316L 106 to $150 \mu \mathrm{m}$ powder, compared to $<0.02 \mathrm{wt}$ pct for the other two powders, corroborated in Table $\mathrm{X}$ which illustrates that the 316L 106 to $150 \mu \mathrm{m}$ powder also had the highest Ti concentration in XPS, confirming that the Ti is partly retained during the manufacturing of the $316 \mathrm{~L} 106$ to $150 \mu \mathrm{m}$ powder. Examining the $\mathrm{Ti} 2 p$ region more closely, as shown in supplementary Figure S-8, contributions from both metallic $\mathrm{Ti}$ and $\mathrm{TiO}_{2}$ were observed in the $316 \mathrm{~L} 106$ to $150 \mu \mathrm{m}$ powder.

It is, however, of interest to note that despite all the three steel powder conditions having a $\mathrm{Sn}$ content in the base composition of $<0.02$ wt pct (arising from feedstock steels having a low Sn content of $0.011 \mathrm{wt}$ pct for the 316L 106 to $150 \mu \mathrm{m}$ sample and a very low $\mathrm{Sn}$ content of $0.005 \mathrm{wt}$ pct for the 17-4PH sample), the $\mathrm{Sn}$ $3 d$ peak was only present in the 17-4PH 106 to $150 \mu \mathrm{m}$ sample, with the peak positions indicative of Sn oxides, as shown in supplementary Figure S-9. The same trend was observed for $\mathrm{P}$, with only the 17-4PH powder containing a concentration above the XPS detection limit, see Table $\mathrm{X}$. The data in the $\mathrm{P} 2 p$ region were rather noisy and overlap with the $\mathrm{Cu} 3 s$ photoemission, but suggested the existence of elemental phosphorus and phosphates. This again corresponds with the iron oxide layer being very much thinner for the 17-4PH 106 to 150 $\mu \mathrm{m}$ case than the other two steels. In agreement with the XPS results reported by Heiden et al. ${ }^{[57]}$ on $316 \mathrm{~L}$ powder feedstock both in the as-received condition and after being reused in the laser bed fusion process, Sn and $\mathrm{Cu}$ were not detected by XPS on the surface of the two $316 \mathrm{~L}$ powders of the present investigation. These findings, however, differed from those published earlier (having residual levels of $0.086 \mathrm{wt}$ pet $\mathrm{Cu}$ and $<0.005 \mathrm{wt}$ pct $\mathrm{Sn}$ ) in that $\mathrm{Cu}$ and $\mathrm{Sn}$ (as well as $\mathrm{S}$ ) were detected on the surface of fine $(<28 \mu \mathrm{m})$ and coarse $(250$ to $350 \mu \mathrm{m})$ martensitic stainless steel powders by the use of various spectroscopy techniques, including XPS, AES, and SIMS. ${ }^{[60]}$

Returning to the $\mathrm{Cu}$ content of the 17-4PH powder, the $\mathrm{Cu} 2 p_{3 / 2}$ region was collected both before and after 

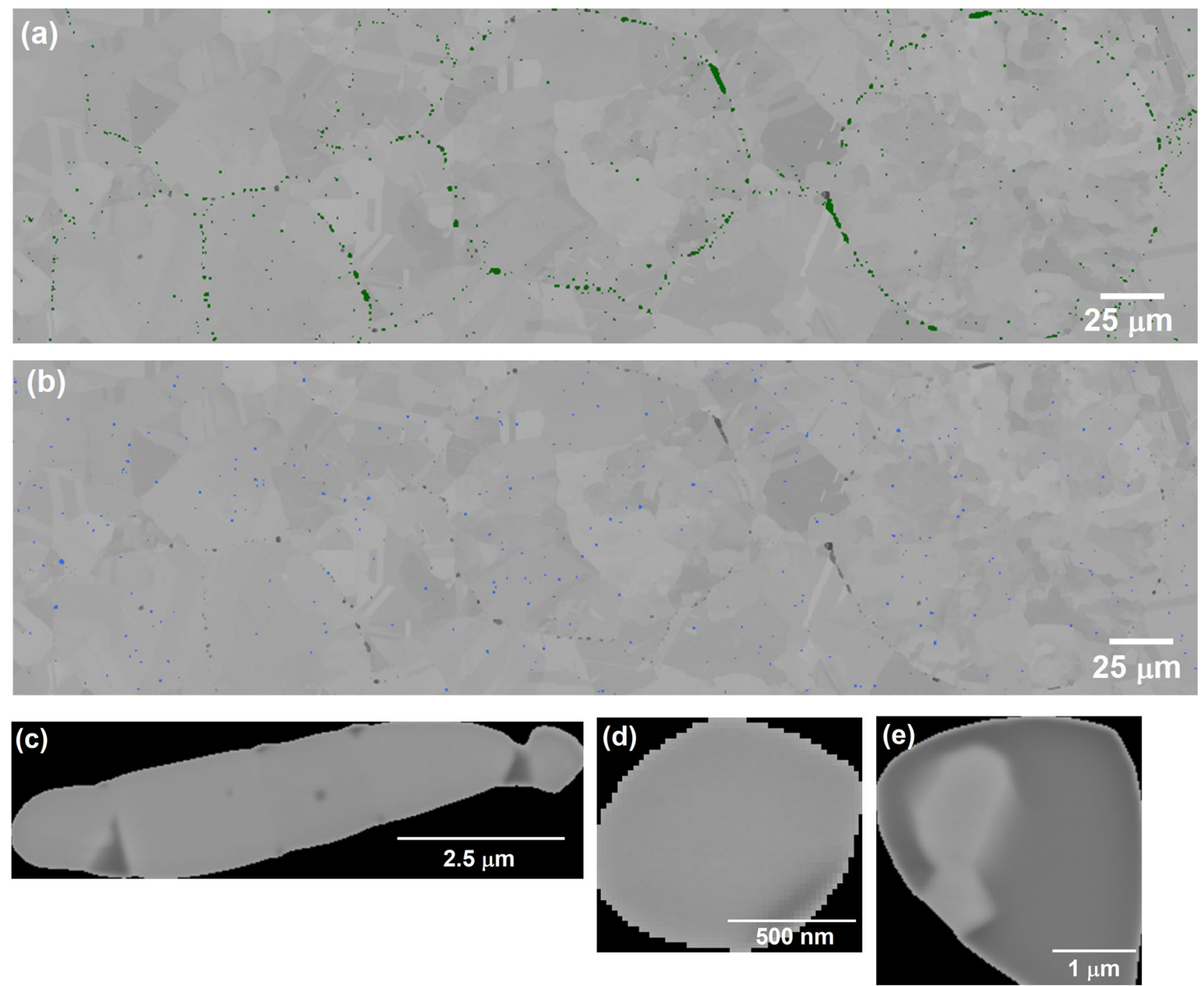

Fig. 7-Inclusions maps for the HIP'd 316L 106 to $150 \mu \mathrm{m}$ sample showing (a) Cr-containing inclusions; $(b)$ Cu-containing inclusions; and examples of specific inclusions: $(c)$ a $\mathrm{Cr}-\mathrm{Mn}-\mathrm{Ti}-\mathrm{V}-\mathrm{Si}$-containing oxide inclusion; $(d)$ a $\mathrm{Cr}-\mathrm{Mn}$-Ti-V-containing oxide inclusion; and $(e)$ a Cr-Mn-Ti-Si-Al oxysulfide inclusion.

sputtering. The data in supplementary Figure S-10 show that spectrum from the as-received powder is dominated by a broad main peak around $934 \mathrm{eV}$ and satellite peaks indicative of $\mathrm{Cu}$ (II) species. After sputtering these $\mathrm{Cu}(\mathrm{II})$ compounds had been removed, resulting in a downward shift of the main $\mathrm{Cu} 2 p_{3 / 2}$ component to $933 \mathrm{eV}$ and the elimination of the satellite peaks, revealing a spectrum comprising approximately $60 \mathrm{wt}$ pct $\mathrm{Cu}_{2} \mathrm{O}$ and $40 \mathrm{wt}$ pct $\mathrm{Cu}(0)$. This indicates that the $\mathrm{Cu}(\mathrm{II})$ compounds are at the surface initially but are easily removed under by ion beam.
In the aforementioned study by Hryha et al., ${ }^{[16]}$ $\mathrm{Cr}-\mathrm{Mn}$-Si-rich oxide particulates were reported on the surface of $316 \mathrm{~L}$ steel powder. Supplementary Figure $\mathrm{S}-11$ shows the $\mathrm{Cr} 2 p_{3 / 2}$ and $\mathrm{Si} 2 p$ regions from the three powders studied in this investigation, confirming the existence of $\mathrm{Cr}$ and $\mathrm{Si}$ oxides in all three powders in the as-received condition. The determination of the $\mathrm{Cr}$ oxidation state on the surface of metallic powders is of special importance for risk assessment on occupational health and safety in relation to hazardous substances. ${ }^{[30]}$ The presence of $\mathrm{Cr}(\mathrm{III})$, and more 


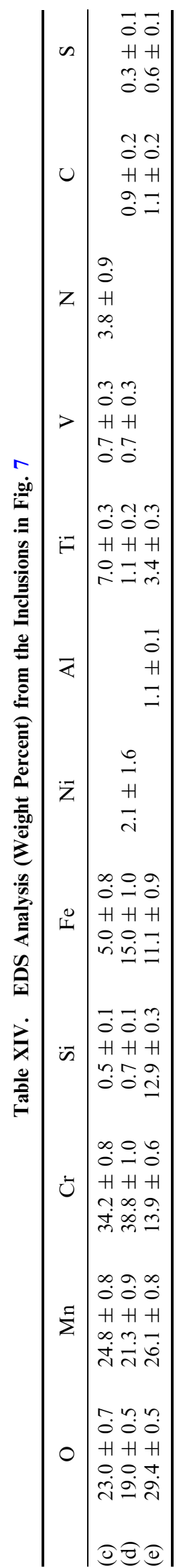

importantly the absence of $\mathrm{Cr}(\mathrm{VI})$, on the surface oxides of the three powders of the present investigation has also been found on the surface of inert gas-atomized $316 \mathrm{~L}$ powders $<45 \mu \mathrm{m}$ and $<4 \mu \mathrm{m}^{[30]}$ and nitrogen gas-atomized $12 \mathrm{Cr}$ steel powder. ${ }^{[61]}$

\section{HIP'd 316L and 17-4PH Stainless Steels}

Exemplified inclusion analysis on the SEM images from the AMGA powder $<150 \mu \mathrm{m}$ (Figure 4 and Table VIII) and VIGA powder 106 to $150 \mu \mathrm{m}$ (Figure 5 and Table IX) to the two HIP'd conditions AMGA HIP'd $<150 \mu \mathrm{m}$ (Figure 6 and Table XIII) and VIGA HIP'd 106 to $150 \mu \mathrm{m}$ (Figure 7 and Table XIV) suggests that the larger globular inclusions in the HIP'd product were carried over from powder to the HIP'd product. Furthermore, Mn-Ti-(V)-Si-Al-containing inclusions in the 316L powder (see Figures 4 and 5 and Tables VIII and IX) can also evolve to two phases during HIP consolidation (Figures 6(c), 8, and 9). Close examination (Figure 8(b) and Table XV) also reveals an outer, single-phase shell of a Cr-Mn-Ti-(V)-Al-containing oxide and an inner core that consisted of a cluster of generally disconnected small particles (up to around 1 $\mu \mathrm{m}$ in size) of Cr-Mn-Ti-(V)-Al-containing oxides joined by a $\mathrm{Mn}-\mathrm{Ti}-(\mathrm{V})-\mathrm{Al}$-containing glassy silicate phase. In practice, associations of coarse and complex inclusions may appear as an individual, single-phase inclusion when carrying out inclusion analysis on planar cross-sections.

In the aforementioned studies by Cooper et al.,$^{[3,4]}$ relatively fine $(<1 \mu \mathrm{m})$ and coarse $(1$ to $5 \mu \mathrm{m})$ non-metallic inclusions were analyzed by SE imaging in conjunction with EDS. Cr-Mn- (2 examples), Mn-Si( 2 examples), and $\mathrm{Cr}-\mathrm{Mn}-\mathrm{Si}$-containing (1 example) oxide inclusions were reported in the HIP'd 316L steel. $^{[4]}$ From the point of view of trace impurity elements of $\mathrm{Ti}, \mathrm{Al}$, and $\mathrm{Ca}, \mathrm{Mn}-\mathrm{Si}-0.2 \mathrm{Ti}-(1$ example), Mn-Si-0.4Ti-0.1Al-(1 example) and Mn-Si-0.3Ca-containing (1 example) were found in the $304 \mathrm{~L} / 316 \mathrm{~L}$ steels. ${ }^{[3]}$ Very limited data on compositional analysis of non-metallic inclusions in austenitic stainless steels are available with even less information reported on the presence of residual elements (no reported observations of $\mathrm{Cu}$ presence).

Figure 9 reveals another example of a coarse, two-phase non-metallic inclusion. The inclusion is formed of a cluster of disconnected particles (up to around $5 \mu \mathrm{m}$ in size) of $\mathrm{Cr}-\mathrm{Mn}$-Ti-containing oxides ((V)-Al-free) joined by a Mn-(Ti)-containing glassy silicate phase ((V)-Al-free). However, in this case, the inclusion is triangular in shape. This suggests that the inclusion is located on the prior particle boundary (PPB) triple point, thus indicating some degree of plasticity. An analogy is the surface oxide cleaning by the field-assisted sintering technology (FAST) in which surface oxides can slide from PPBs to triple points. ${ }^{[62]}$ Earlier work on hot-rolled austenitic stainless steel strip reported a complex, two-phase inclusion, which was composed of hard chromium galaxite phase $(36 \mathrm{MnO}$, $1 \mathrm{FeO}, 25 \mathrm{Al}_{2} \mathrm{O}_{3}, 39 \mathrm{Cr}_{2} \mathrm{O}_{3}$ ) embedded in glassy manganese oxide-chromia-alumina-silica $(23 \mathrm{MnO}, 1 \mathrm{FeO}$, 


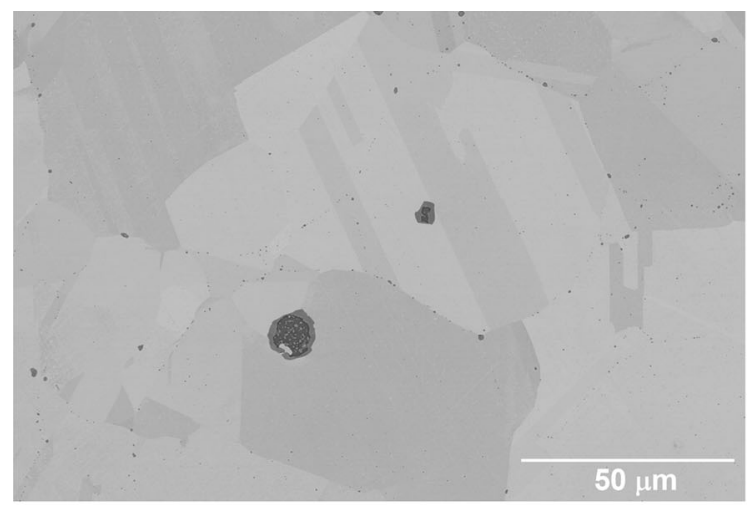

(a)

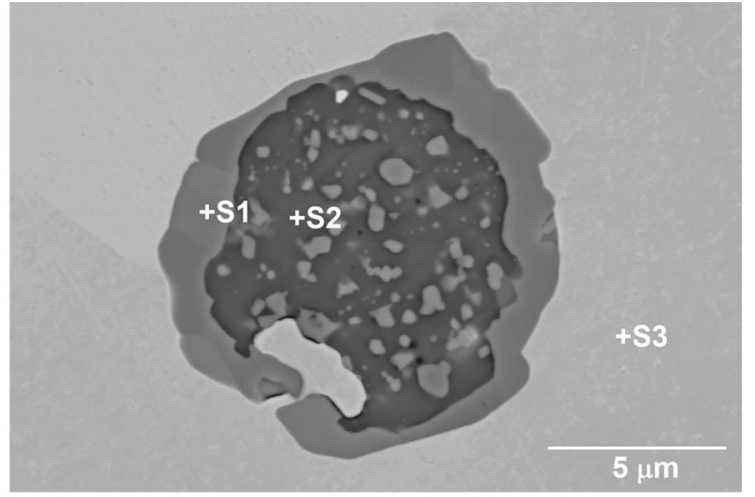

(b)

Fig. 8-BSE micrographs and EDS analysis of the AMGA HIP'd 316L $<150 \mu \mathrm{m}$ sample showing $(a)$ non-metallic inclusions and $(b)$ detail of an outer, single-phase shell of a Cr-Mn-Ti-(V)-Al-containing oxide (S1) and an inner core that consisted of a cluster of generally disconnected small particles (up to around $1 \mu \mathrm{m}$ in size) of $\mathrm{Cr}-\mathrm{Mn}$-Ti-(V)-Al-containing oxides joined by a Mn-Ti-(V)-Al-containing glassy silicate matrix (S2).

$\left.43 \mathrm{SiO}_{2}, 18 \mathrm{Al}_{2} \mathrm{O}_{3}, 4 \mathrm{Cr}_{2} \mathrm{O}_{3}, 8 \mathrm{CaO}\right){ }^{[63]}$ The major similarities between the inclusion shown in Figure 29 of Reference 63 and the inclusion shown in Figure 9 are that both plastic silicate matrixes deform and both hard $\mathrm{Cr}-\mathrm{Mn}$-rich phases remained undeformed during steel deformation. The inclusion in Kiessling and Lange's work, ${ }^{[63]}$ however, showed a greater degree of deformation than that of Figure 9. The globular, two-phase inclusion of Figure 8(b) would have resisted deformation during HIPping as the hard Cr-Mn-Ti-(V)-Al-containing oxide formed as a shell around the plastic silicate, as opposed to the non-shell inclusion of Figure 9.

For the AMGA HIP'd 316L $<150 \mu \mathrm{m}$ sample, inclusions can be observed on the PPBs and within the particles (Figures 6(a) and (b)). The majority of the inclusions were found to be Ti-free $\mathrm{Cr}-\mathrm{Mn}$-rich, decreasing in the order: $\mathrm{Cr} \mathrm{Mn} \mathrm{O} \mathrm{S}\left(19560 \mathrm{~mm}^{-2}\right)>\mathrm{Cr} \mathrm{Mn} \mathrm{O}$ $\left(6740 \mathrm{~mm}^{-2}\right)>\mathrm{Cr}$ Mn S $\left(2222 \mathrm{~mm}^{-2}\right)$ as quantified in Table III and in supplementary Figures S-1(d) and (e). It can also be seen in supplementary Figures S-1(d) and (e) that (i) in the quasi-absence of $\mathrm{Ti}$ retention in the inclusions, $\mathrm{V}$ is mainly retained in the two main type of inclusions above: $\mathrm{Cr} \mathrm{Mn} \mathrm{V} \mathrm{O} \mathrm{S}\left(521 \mathrm{~mm}^{-2}\right)$ and $\mathrm{Cr} \mathrm{Mn}$ $\mathrm{V} \mathrm{O}\left(150 \mathrm{~mm}^{-2}\right)$, and that (ii) residual $\mathrm{Cu}$ is mainly associated with Mn O S $\left(1027 \mathrm{~mm}^{-2}\right)$ and $\mathrm{Mn} \mathrm{S}(864$ $\left.\mathrm{mm}^{-2}\right)$, as opposed to $\mathrm{MnO}\left(42 \mathrm{~mm}^{-2}\right)$.

For the VIGA HIP'd 316L 106 to $150 \mu \mathrm{m}$ sample, the majority of the inclusions are located on the PPBs
(Figures 7(a) and (b)). The majority of the inclusions were $\mathrm{Cr}$-Mn-Ti-rich inclusions with and without $\mathrm{V}$ and decreased in the order of $\mathrm{Cr} \mathrm{Mn} \mathrm{Ti} \mathrm{O}\left(1542 \mathrm{~mm}^{-2}\right)>\mathrm{Cr}$ Mn Ti Si O $\left(1378 \mathrm{~mm}^{-2}\right)>$ Cr Mn Ti Si O S (1030 $\mathrm{mm}^{-2}$ ) as quantified in Table III and in supplementary Figures S-1(f) and (g). It can also be seen in supplementary Figures S-1(f) and $(\mathrm{g})$ that, in the presence of Ti-containing inclusions, $\mathrm{V}$ is mainly associated with the following $\mathrm{Cr}-\mathrm{Mn}$-Ti-rich inclusions types: $\mathrm{Cr} \mathrm{Mn} \mathrm{Ti} \mathrm{V}$ Al O oxides $\left(390 \mathrm{~mm}^{-2}\right), \mathrm{Cr} \mathrm{Mn} \mathrm{Ti} \mathrm{V} \mathrm{O} \mathrm{oxides} \mathrm{(310}$ $\left.\mathrm{mm}^{-2}\right)$, and Cr Mn Ti V Al O S oxysulfides $\left(242 \mathrm{~mm}^{-2}\right)$. Higher $\mathrm{N}$ levels are also retained in the VIGA and HIP materials as compared to the AMGA and HIP materials (Tables I and II). Some examples of N-containing inclusions of the type of sulfides and oxysulfides are split in supplementary Figure S-1(g). Again, residual $\mathrm{Cu}$ is mainly associated with $\mathrm{Mn} \mathrm{O} \mathrm{S}\left(3579 \mathrm{~mm}^{-2}\right)$ and $\mathrm{Mn}$ $\mathrm{S}\left(1802 \mathrm{~mm}^{-2}\right)$, as opposed to $\mathrm{Mn} \mathrm{O}\left(21 \mathrm{~mm}^{-2}\right)$.

The association of residual $\mathrm{Cu}$ with $\mathrm{Mn} \mathrm{S}$ and $\mathrm{Mn} \mathrm{OS}$ overwhelmingly outweighed that of Mn O in both HIP'd 316L samples (Table III). The smaller numbers of these particles fell in the size range 0 to $1 \mu \mathrm{m}$, representing most of the particles (Table V). Isolated examples of $\mathrm{Cu}$ $\mathrm{Mn} \mathrm{O} \mathrm{S}$ having a maximum dimension of up to $4 \mu \mathrm{m}$ were observed (Table $\mathrm{V}$ ). This association of residual $\mathrm{Cu}$ with $\mathrm{Mn} \mathrm{S}$ and $\mathrm{Mn} \mathrm{O} \mathrm{S}$ has strategic implications for both $\mathrm{Cu}$ residual tolerance levels and standardization. Earlier work reported in Reference 64 showed that residual $\mathrm{Cu}(0.14 \mathrm{wt}$ pet $)$ has been found to combine 
with $\mathrm{S}(0.043 \mathrm{wt}$ pct) to form $\mathrm{CuS}$, which precipitates on existing $\mathrm{MnS}$ inclusions. More recently, a detailed review of metal oxysulfides was published by Larquet and Carenco, ${ }^{[65]}$ in which it was reported that, $\mathrm{Cu}$ can form several oxysulfides such as $\mathrm{Cu}_{2} \mathrm{O}_{1-x} \mathrm{~S}_{x}, \mathrm{Sr}_{2} \mathrm{Cu}_{2} \mathrm{M}$ $\mathrm{nO}_{2} \mathrm{~S}_{2}$, and $\mathrm{Sr}_{2} \mathrm{CuMO}_{3} \mathrm{~S}(\mathrm{M}=\mathrm{Sc}, \mathrm{Cr}, \mathrm{Fe})$.

From Table II for the Cu alloyed HIP'd 17-4PH steel, which had a very low $\mathrm{S}$ content of 0.0010 wt pet, it is clear that the formation of oxysulfides was suppressed and the formation of $\mathrm{Cu} \mathrm{O}$ was much more favorable than the formation of $\mathrm{Cu} \mathrm{Mn} \mathrm{O}$. The majority of these particles also fell in the smallest size range 0 to $1 \mu \mathrm{m}$, (Table VI).

\section{E. Standardization Implications}

Overall, these results have important implications for the development of standardization tools for residuals elements as well as cross-contamination for quality control of raw materials introduced in the supply chain as very small amounts of contamination can be identified in powders.

Note that, the level of residual $\mathrm{Cu}$ in powder $316 \mathrm{~L}$ steel is not generally explicitly quoted in the literature ${ }^{[2-4,30,66-72]}$ and other powder stainless steels, ${ }^{[68]}$ for example AISI 304L ${ }^{[31]}$ and 304. ${ }^{[66]} \mathrm{A}$ few examples in which the level of residual $\mathrm{Cu}$ was reported are 0.05-0.06 wt pct in HIP'd 316L, ${ }^{[5]} 0.05$ wt pct $\mathrm{Cu}$ in a water-atomized $316 \mathrm{~L}$ powder ${ }^{[30]}$ and 0.2 wt pet $\mathrm{Cu}$ in a gas-atomized $316 \mathrm{~L}$ steel powder ${ }^{[51]}$ and $<0.1$ wt pet in a $304 \mathrm{~L}$ powder. ${ }^{[74,75]}$ Sometimes, the chemical analysis is not specifically reported for a steel powder, but may be reported for the corresponding consolidated product, an example is a $\mathrm{Cu}$ residual value of $0.015 \mathrm{wt}$ pct in $\mathrm{AM}$ AISI 304L. ${ }^{[76]}$ Those $\mathrm{Cu}$ residual levels are generally less than half the value of $0.2 \mathrm{wt}$ pct reported in Reference 33 that could be detrimental to the hot workability of the steel.

The aforementioned association of residual $\mathrm{Cu}$ with both Mn S and Mn O S in both HIP'd 316L steels of the present investigation suggests that residual levels of $\mathrm{Cu}$ $<0.5$ wt pct could be bound to both $\mathrm{MnS}$ and $\mathrm{Mn} \mathrm{O} \mathrm{S}$ inclusions in $316 \mathrm{~L}$ steel for HIPping applications, ultimately leading to allowing an increased usage of steel scraps - containing high levels of $\mathrm{Cu}$ impurity - for powder atomization processes.

\section{CONCLUSIONS}

This paper empirically analyses how non-metallic inclusions evolved through processing from feedstock to powder and after HIP consolidation in Ti-V microalloyed $316 \mathrm{~L}$ and $\mathrm{Al}-\mathrm{V}$ microalloyed $17-4 \mathrm{PH}$ stainless steels. Using enhanced oxygen levels in the powders from powder handling, the evolution of non-metallic inclusions through processing has been documented. Consideration has also been made to determine the change in $\mathrm{Ti}, \mathrm{V}$, and $\mathrm{Cu}$ contents in both stainless steels. The main conclusions are as follows: 

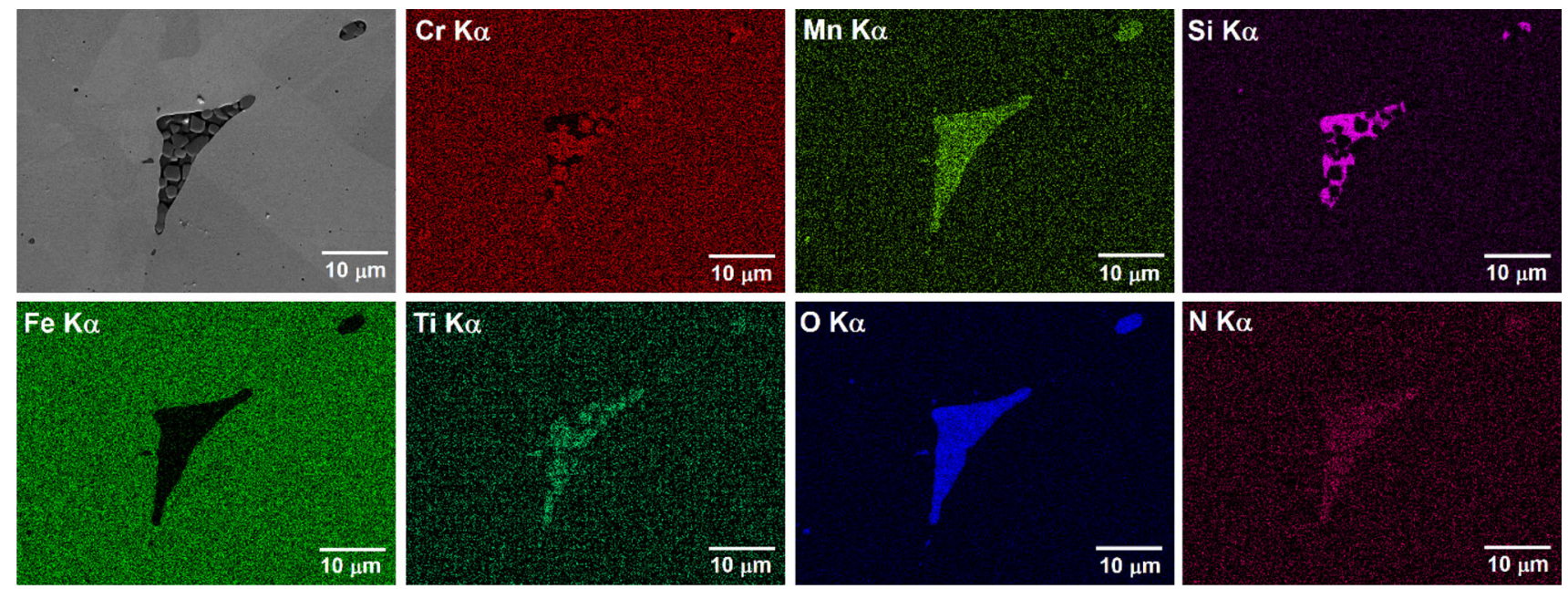

Fig. 9-Inclusion maps for the VIGA HIP'd 316L 106 to $150 \mu \mathrm{m}$ sample.
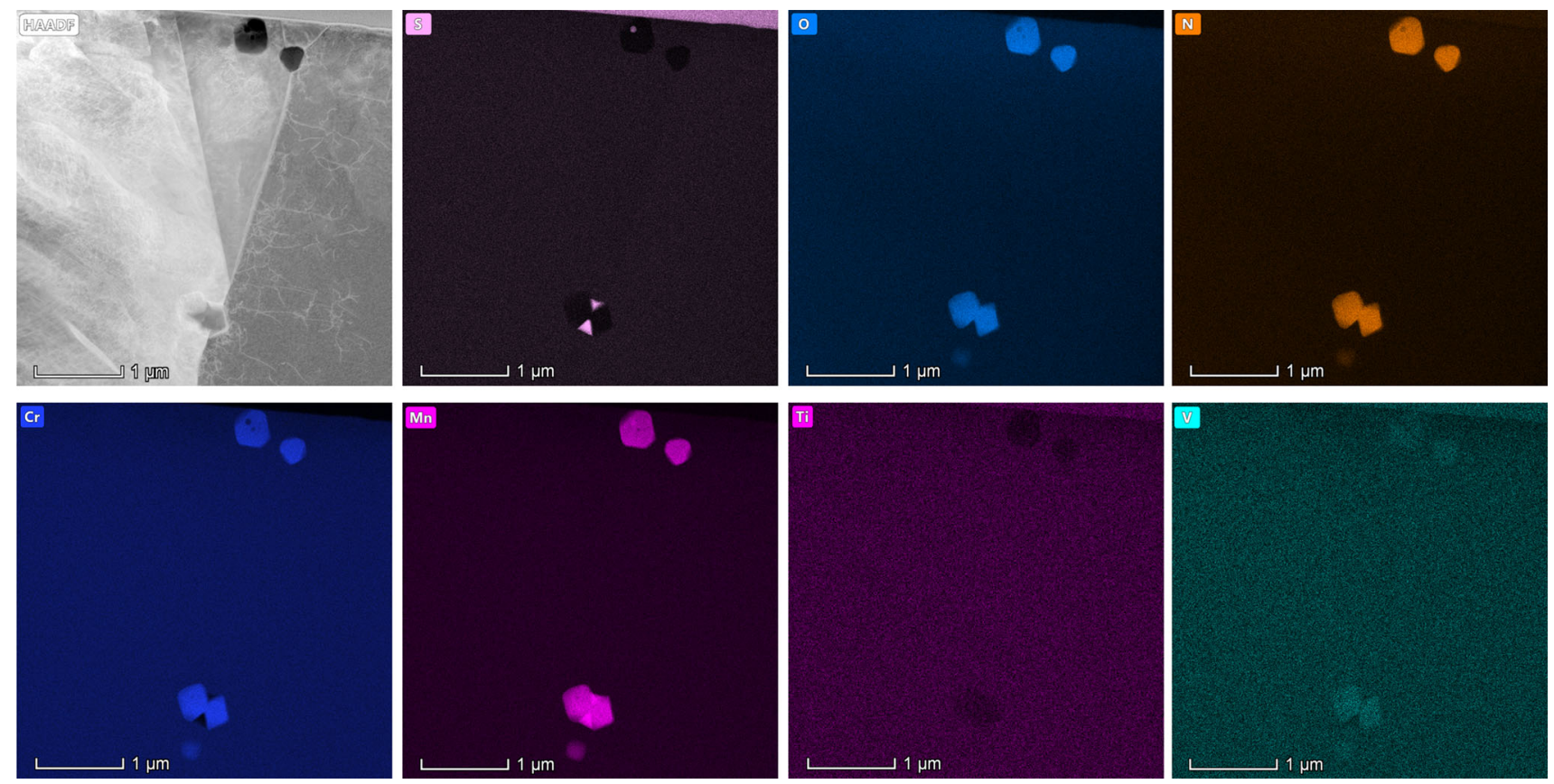

Fig. 10-TEM micrographs of the AMGA HIP'd 316L $<150 \mu \mathrm{m}$ sample showing a HAADF-STEM image and EDXS elemental maps.

1. Microalloyed $\mathrm{Ti}$ was lost during air melting but partly retained after vacuum melting leading to the presence of fine and complex Ti-containing precipitates. Microalloyed V was retained in the melt by the use of both AMGA and VIGA processes, and therefore available for precipitation during HIPping. Residual $\mathrm{Cu}$ was retained during both air and vacuum melting and was associated with $\mathrm{Mn} \mathrm{S}$ and $\mathrm{Mn} \mathrm{O} \mathrm{S}$ inclusions overwhelmingly outweighing that of simple $\mathrm{Mn} \mathrm{O}$ in the two HIP'd $316 \mathrm{~L}$ samples.
2. There were significant differences between the dominant types of inclusions through processing in Ti-V microalloyed $316 \mathrm{~L}$ and $\mathrm{Al}-\mathrm{V}$ microalloyed $17-4 \mathrm{PH}$ stainless steels. These were

Mn Ti N S (TiN/MnS) for the 316L steel feedstock; Mn Ti Si Al oxides in the $316 \mathrm{~L}<150 \mu$ m powder; Ti Si $\mathrm{Al}$ oxides for the $316 \mathrm{~L} 106$ to $150 \mu \mathrm{m}$ powder: Ti-free Cr-Mn-rich oxides, sulfides, and oxysulfides for the HIP'd 316L $<150 \mu \mathrm{m}$ steel and both Cr-Mn-Ti-(V)-rich oxides and oxysulfides in the HIP'd 316L 106 to $150 \mu \mathrm{m}$ steel. 

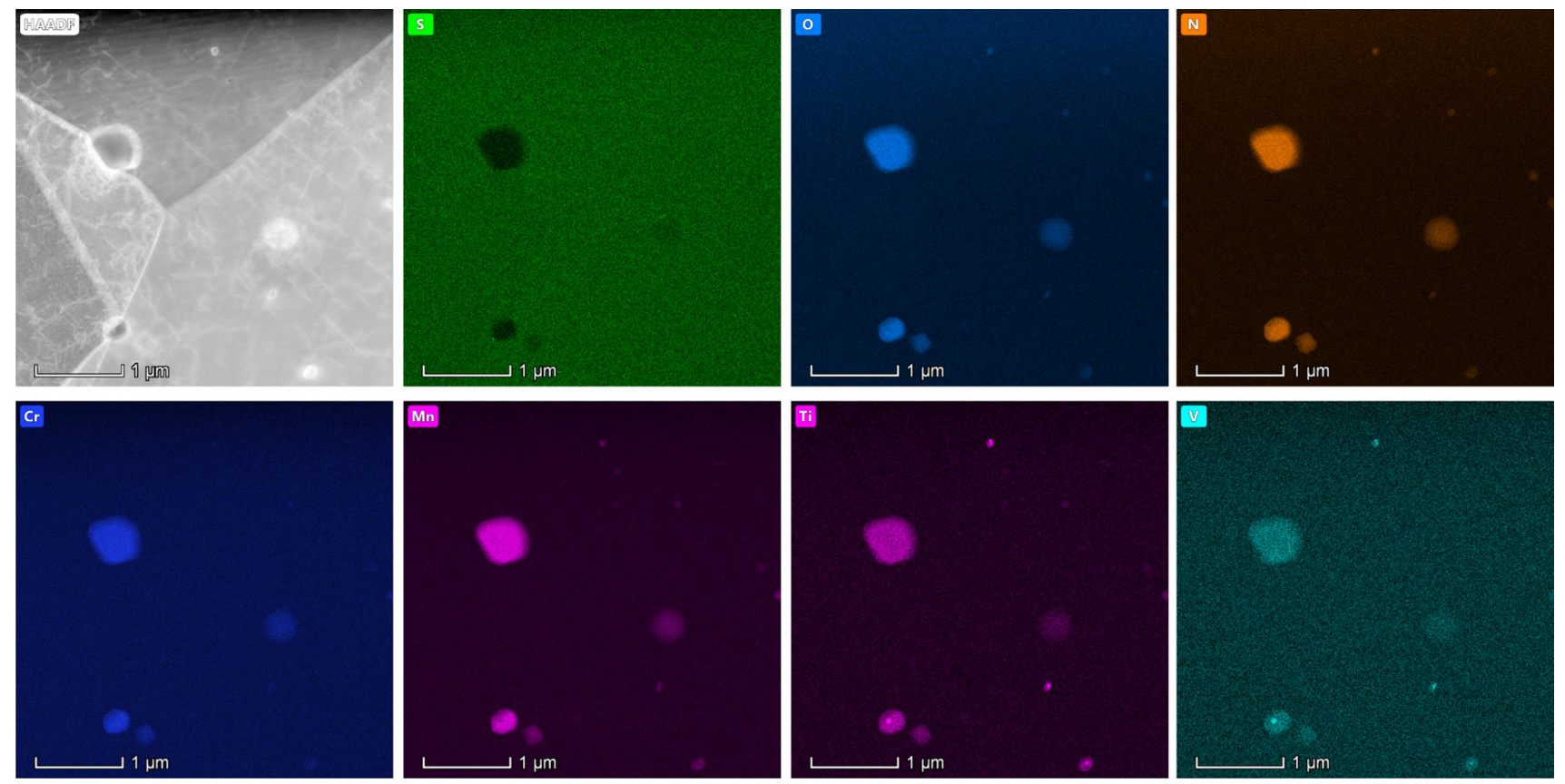

Fig. 11-TEM micrographs of the VIGA HIP'd 316L 106 to $150 \mu \mathrm{m}$ sample showing a HAADF-STEM image and EDXS elemental maps.

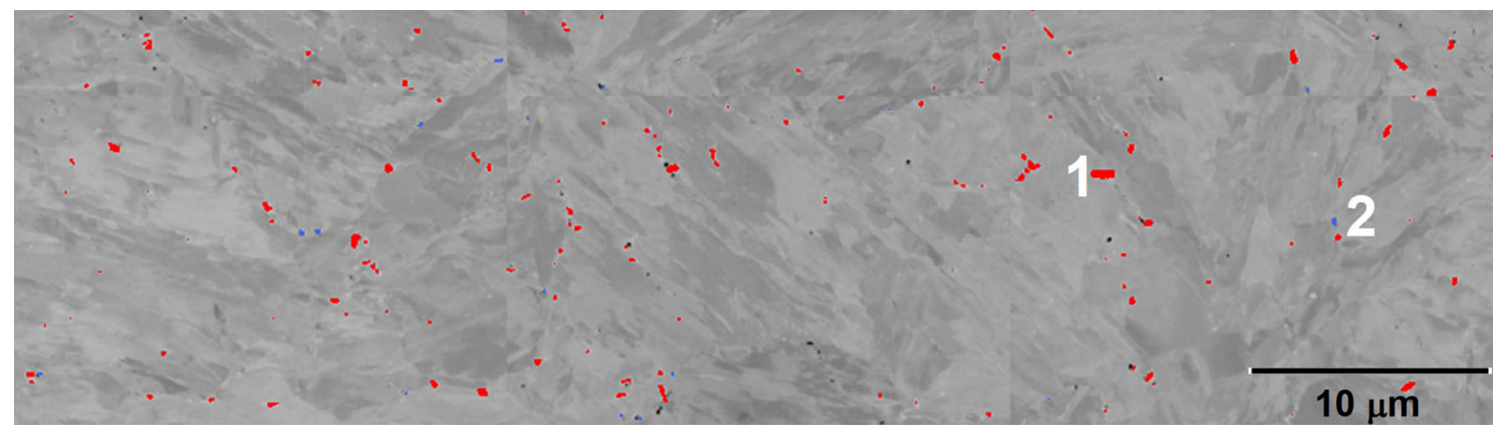

Fig. 12-Phase map for the VIGA HIP'd 17-4PH 25 to $45 \mu \mathrm{m}$ sample showing Nb-Cr-V-Cu-containing (red 1) and Cu-rich (blue 2) phases (Color figure online).

Table XVI. EDS Analysis (Weight Percent) from the Phases in Fig. 12

\begin{tabular}{|c|c|c|c|c|c|c|c|c|c|}
\hline Phase & $\mathrm{Nb}$ & $\mathrm{Cr}$ & $\mathrm{Fe}$ & $\mathrm{N}$ & V & $\mathrm{Cu}$ & $\mathrm{Ni}$ & Mo & $\mathrm{C}$ \\
\hline 1 & $37.8 \pm 0.6$ & $27.7 \pm 0.5$ & $25.7 \pm 0.6$ & $4.9 \pm 0.3$ & $2.0 \pm 0.2$ & $1.2 \pm 0.2$ & $0.4 \pm 1.0$ & $0.3 \pm 0.4$ & \\
\hline 2 & & $6.8 \pm 0.3$ & $27.6 \pm 0.5$ & & & $62.5 \pm 0.5$ & & $0 \pm 0.2$ & $3.0 \pm 0.2$ \\
\hline
\end{tabular}

Isolated examples of inclusions were observed for both $17-4 \mathrm{PH}$ steel feedstock $(0.0009 \mathrm{~S}-0.0010 \mathrm{O}-0.030 \mathrm{~N}$ (wt pct)) and powder (0.0010S-0.03180-0.0351N (wt pct)) but in insufficient number to be significant, suggesting that in the powder sample, oxygen was mainly present in the form of surface oxides. Low-Cr oxides without $\mathrm{Nb}, \mathrm{Ti}$, and $\mathrm{V}$ were the dominant inclusion type for the HIP'd $25-45 \mu \mathrm{m}$ sample that had a very low sulfur content of $0.0010 \mathrm{wt}$ pet and an oxygen content of $0.0216 \mathrm{wt}$ pct, and therefore exhibited the lowest number density of sulfides and oxysulfides compared to the two HIP'd 316L samples.

3. The Ti content in the $316 \mathrm{~L}$ steel varied from $0.13 \mathrm{wt}$ pct Ti in the feedstock to low residual levels in the AMGA samples: $<0.02 \mathrm{wt}$ pct $\mathrm{Ti}$ in the powder and $<0.005$ wt pet Ti in the HIP'd $<150 \mu$ m sample, whereas it was partly retained to relatively high 
levels in the VIGA samples: $0.046 \mathrm{wt}$ pct $\mathrm{Ti}$ in the powder and $0.05 \mathrm{wt}$ pct in the HIP'd 106 to $150 \mu \mathrm{m}$ sample. In the latter case, Ti-rich precipitates were observed by HAADF-STEM in conjunction with EDX to provide pinning of grain boundaries, resulting in a smaller mean austenite grain size value of $17.3 \pm 15.4$ compared with $23.1 \pm 21.6$ for the AMGA HIP'd $<150 \mu \mathrm{m}$ sample.

4. XPS analysis revealed the presence of many different elements in their metallic and oxidized compounds, within the three steel powders examined (VIGA $316 \mathrm{~L} 106$ to $150 \mu \mathrm{m}$, VIGA $316 \mathrm{~L} 15$ to 45 $\mu \mathrm{m}$, and 17-4PH 106 to $150 \mu \mathrm{m})$. The common peaks in all three samples were $\mathrm{Fe} 2 p-\mathrm{Fe}(0), \mathrm{FeO}$ and $\mathrm{Fe}_{2} \mathrm{O}_{3} ; \mathrm{Cr} 2 p-\mathrm{Cr}(0)$ and $\mathrm{Cr}(\mathrm{III}) ; \mathrm{Si} 2 p-\mathrm{Si}(0)$ and $\mathrm{SiO}$; $\mathrm{O} 1 s$ and $\mathrm{C} 1 s$; with common peaks only for the two $316 \mathrm{~L}$ powders $\mathrm{Si} 2 p-\mathrm{SiO}_{2} ; \mathrm{Mo}$ $3 d-\mathrm{Mo}(0)$ and $\mathrm{MoO}_{3} ; \mathrm{Ni} 2 p-\mathrm{Ni}(0)$ and $\mathrm{Ni}(\mathrm{II})$ and $\mathrm{Mn} 2 p-\mathrm{Mn}(0)$ and $\mathrm{MnO}$ and with particular peaks for the $316 \mathrm{~L} 106-150 \mu \mathrm{m}$ powder $\mathrm{Ti}$ $2 p-\mathrm{Ti}(0)$ and $\mathrm{TiO}_{2}$; with particular peaks for the 17-4PH $106-150 \mu \mathrm{m}$ powder $\mathrm{Sn} 3 d-\mathrm{Sn}(0)$ and $\mathrm{SnO} / \mathrm{SnO}_{2} ; \mathrm{N}$ 1s and $\mathrm{Nb} 3 d-\mathrm{Nb}(0), \mathrm{NbO}_{2}, \mathrm{NbC} /$ $\mathrm{NbN} ; \quad \mathrm{P} 2 p-\mathrm{P}(0)$ and phosphates and $\mathrm{Cu}$ $2 p-\mathrm{Cu}(\mathrm{II})$ in the as-received condition only, but both $\mathrm{Cu}_{2} \mathrm{O}$ and $\mathrm{Cu}(0)$ after $\mathrm{Ar}^{+}$sputtering only.

5. A thin oxide film formed on the powder surface, thicker for the $316 \mathrm{~L}$ powder than the $17-4 \mathrm{PH}$ powder as indicated by XPS analysis of selected powder precursors.

\section{ACKNOWLEDGMENTS}

The financial support of Liberty Powder Metals is gratefully acknowledged. This work was carried out as part of the UK government's Advanced Manufacturing Supply Chain Initiative (AMSCI) - CASCADE project.

\section{OPEN ACCESS}

This article is licensed under a Creative Commons Attribution 4.0 International License, which permits use, sharing, adaptation, distribution and reproduction in any medium or format, as long as you give appropriate credit to the original author(s) and the source, provide a link to the Creative Commons licence, and indicate if changes were made. The images or other third party material in this article are included in the article's Creative Commons licence, unless indicated otherwise in a credit line to the material. If material is not included in the article's Creative Commons licence and your intended use is not permitted by statutory regulation or exceeds the permitted use, you will need to obtain permission directly from the copyright holder. To view a copy of this licence, visit http://creat ivecommons.org/licenses/by/4.0/.

\section{ELECTRONIC SUPPLEMENTARY MATERIAL}

The online version of this article (https://doi.org/10. 1007/s11661-020-06010-w) contains supplementary material, which is available to authorized users.

\section{REFERENCES}

1. Stainless Steels, 2nd ed., J.R. Davis, ed., Stainless Steels, ASM Speciality Handbook. ASM International, Materials Park, OH, 1994.

2. S. Irukuvarghula, H. Hassanin, C. Cayron, M.M. Attallah, D. Stewart and M. Preuss Acta Mater., 2017, vol. 133, pp. 269-81.

3. A.J. Cooper, N.I. Cooper, A. Bell, J. Dhers, and A.H. Sherry: Metall. Mater. Trans. A, 2015, vol. 46A (11), pp. 5126-38.

4. A.J. Cooper, N.I. Cooper, A. Bell, J. Dhers, and A.H. Sherry: Metall. Mater. Trans. A, 2016, vol. 47A (9), pp. 4467-75.

5. A.J. Cooper, W.J. Brayshaw, and A.H. Sherry: Metall. Mater. Trans. A, 2018, vol. 49A (5), pp. 2018-79.

6. U. Engström and E. Schneider: in World Congress on Powder Metallurgy, Proceedings of World PM2018, Beijing, China, 16-20 September 2018, pp. 43-52.

7. V. Polard and B. Blitz: in World Congress on Powder Metallurgy, Proceedings of World PM2018, Beijing, China, 16-20 September 2018, pp. 1152-55.

8. R. Goto: in World Congress on Powder Metallurgy, Proceedings of World PM2018, Beijing, China, 16-20 September 2018, pp. 1979-82.

9. P. Gundermann: in Euro PM2018 Plenary presentation, Bilbao, Spain, 14-18 October 2018. https://www.europm2018.com/onsi te-content-access. Accessed 24 June 2020.

10. P. Bajaj, A. Hariharan, A. Kini, P. Kürnsteiner, D. Raabe, and E.A. Jägle: Mater. Sci. Eng. A, 2020, vol. 772, p. 138633.

11. N. Li, S. Huang, G. Zhang, R. Qin, W. Liu, H. Xiong, G. Shi, and J. Blackburn: J. Mater. Sci. Technol., 2019, vol. 35 (2), pp. 242-69.

12. H. Fayazfar, M. Salarian, A. Rogalsky, D. Sarker, P. Russo, V. Paserin, and E. Toyserkani: Mater. Des., 2018, vol. 144, pp. $98-128$.

13. J. Dawes, R. Bowerman, and R. Trepleton: Johnson Matthey Technol. Rev., 2015, vol. 59 (3), pp. 243-56.

14. H. Men and Z. Fan: Mater. Sci. Technol., 2011, vol. 27 (6), pp. $1033-39$.

15. H.J.T. Ellingham: J. Soc. Chem. Ind., 1944, vol. 63, pp. 125-33.

16. E. Hryha, R. Shvab, H. Gruber, A. Leicht and L. Nyborg: in Euro PM2017 Proceedings, Milan, Italy, 1-5 October 2017.

17. M.J. Balart, X. Hao, S. Marks, G.D. West, M. Strangwood and C.L. Davis: in World Congress on Powder Metallurgy, Proceedings of World PM2018, Beijing, China, 16-20 September 2018, pp. $86-91$.

18. M.J. Balart, H.G.C. Hamilton, X. Hao, M. Strangwood and C.L. Davis: in Euro PM2018 Proceedings, 14-18 October, Bilbao, Spain.

19. Y. Sun, R.J. Hebert, and M. Aindow: Mater. Des., 2017, vol. 140, pp. 153-62.

20. M. Nuspl, W. Wegscheider, J. Angeli, W. Posch, and M. Mayr: Anal. Bioanal. Chem., 2004, vol. 379, pp. 640-45, https://doi.org/ 10.1007/s00216-004-2528-y.

21. B. Goulart Bartosiaki, J.A. Morales Pereira, W. Viana Bielefeldt and A.C. Faria Vilela: J. Mater. Res. Technol., 2015, vol. 4 (3), pp. $235-40$.

22. E. Santecchia, P. Mengucci, A. Gatto, E. Bassoli, L. Denti, F. Bondioli and G. Barucca: in Euro PM2018 Proceedings, Bilbao, Spain, 14-18 October 2018.

23. E. Santecchia, P. Mengucci, A. Gatto, E. Bassoli, S. Defanti, and G. Barucca: Materials, 2019, vol. 12, p. 2342, https://doi.org/ $10.3390 / \mathrm{ma} 12152342$

24. T.F. Murphy, C.T. Schade and A. Zwiren (2018): Int. J. Powder Metall., 2018, vol. 54 (1), pp. 47-59.

25. P. Kaushik, J. Lehmann, and M. Nadif: Metall. Mater. Trans. B, 2012, vol. 43B (4), pp. 710-25. 
26. P. Kaushik, H. Pielet, and H. Yin: Ironmaking Steelmaking, 2009, vol. 36 (8), pp. 561-71, https://doi.org/10.1179/ 030192309X12492910938131.

27. P. Kaushik, H. Pielet, and H. Yin: Ironmaking Steelmaking, 2009, vol. $36 \quad(8), \quad$ pp. $\quad 572-82, \quad$ https://doi.org/10.1179/ $030192309 \times 12492910938177$.

28. A.D. Brandão, R. Gerard, J. Gumpinger, S. Beretta, A. Makaya, L. Pambaguian, and T. Ghidini: Materials, 2017, vol. 10, p. 522 , https://doi.org/10.3390/ma10050522.

29. E. Klar and P.K. Samal: Powder Metallurgy Stainless Steels: Processing, Microstructures, and Properties, ASM International, Materials Park, OH, 2007, pp. 30-32. https://books.google.co.u $\mathrm{k} /$ books?isbn $=1615030522$. Accessed 12 Nov 2018.

30. Y. Hedberg, M. Norell, J. Hedberg, P. Szakálos, P. Linhardt and I. Odnevall Wallinder: Powder Metall., 2013, vol. 56 (2), pp. $158-63$.

31. A.J. Cooper, W.J. Brayshaw, and A.H. Sherry: Metall. Mater. Trans. A, 2018, vol. 49A (3), pp. 811-16.

32. H. Ohno, K. Matsubae, K. Nakajima, Y. Kondo, S. Nakamura, Y. Fukushima, and T. Nagasaka: Environ. Sci. Technol., 2017, vol. 51 (22), pp. 13086-94.

33. H. Katayama, N. Sano, M. Sasabe, and S. Matsuoka: Scand. J. Metall., 1998, vol. 27 (1), pp. 24-30.

34. P.C. Rem, F. van den Broeck, and M.C.M. Bakker: Ironmaking Steelmaking, 2012, vol. 39 (7), pp. 504-07, https://doi.org/10.1179/ 1743281212 Y.0000000017.

35. J.K.S. Tee and D.J. Fray: Ironmaking Steelmaking, 2006, vol. 33 (1), pp. 19-23, https://doi.org/10.1179/174328106X80028.

36. M.B. Mesina, T.P.R. de Jong, and W.L. Dalmijn: Int. J. Miner. Process., 2005, vol. 76, pp. 21-31.

37. C.Y. Chen, C.H. Li, T.C. Tsao, P.H. Chiu, S.P. Tsai, J.R. Yang, L.J. Chiang, and S.H. Wang: Mater. Today Commun., 2020, vol. 23, art. no. 100895 .

38. A.M. Sage: in Fundamentals of Microalloying Forging Steels. Ed. G. Krauss and S.K. Banerji, AIME, 1987, pp. 239-53.

39. H. Wei, Y.L. Chen, W. Yu, L. Su, X. Wang, and D. Tang: Construct. Build. Mater., 2020, vol. 239 (117815), pp. 1-13.

40. K.H. Lo, C.H. Shek and J.K.L. Lai. Mater. Sci. Eng., R, 2009, vol. 65 (4-6), pp. 39-104.

41. M.J. Konstantinović, I. Uytdenhouwen, G. Bonny, N. Castin, L. Malerba, and P. Efsing: Acta Mater., 2019, vol. 179, pp. 183-89.

42. G.R. Odette, T. Yamamoto, T.J. Williams, R.K. Nanstad, and C.A. English: J. Nucl. Mater., 2019, vol. 526 (151863), pp. 1-38.

43. N. Almirall, P.B. Wells, T. Yamamoto, K. Wilford, T. Williams, N. Riddle, and G.R. Odette: Acta Mater., 2019, vol. 179, pp. 119-28.

44. B. Mintz: ISIJ Int., 1999, vol. 39 (9), pp. 833-55.

45. A. Bergman and R. West: Scr. Metall., 1988, vol. 22 (5), pp. 659-63.

46. S.A.E. Aerospace, Aerospace Material Specification: AMS 5662, SAE International 2009.

47. K. Kandasamy, O. Messe, S. Foster, S. Kelly and S. Sharma: in Euro PM2018 Proceedings, Bilbao, Spain, 14-18 October 2018.

48. ASTM A542 / A542M-19, Standard Specification for Pressure Vessel Plates, Alloy Steel, Quenched-and-Tempered, Chromium-Molybdenum, and Chromium-Molybdenum-Vanadium, ASTM International, West Conshohocken, PA, 2019, www.astm. org.

49. ASTM A508 / A508M-18, Standard Specification for Quenched and Tempered Vacuum-Treated Carbon and Alloy Steel Forgings for Pressure Vessels, ASTM International, West Conshohocken, PA, 2018, www.astm.org.

50. ASTM A988 / A988M-17: Standard Specification for Hot Isostatically-Pressed Stainless Steel Flanges, Fittings, Valves, and
Parts for High Temperature Service, ASTM International, West Conshohocken, PA, 2017, www.astm.org.

51. N.P. Lavery, J. Cherry, S. Mehmood, H. Davies, B. Girling, E. Sackett, S.G.R. Brown, and J. Sienz: Mater. Sci. Eng. A, 2017, vol. 693, pp. 186-213.

52. Y. Sun, R. Hebert, and M. Aindow: Mater. Des., 2018, vol. 156, pp. 429-40

53. N. Fairley, Fairley, http://www.casaxps.com, (C) Casa software Ltd., 2018.

54. M.J. Balart, C.L. Davis, and M. Strangwood: Mater. Sci. Eng. A, 2000, vol. 284 (1-2), pp. 1-13.

55. X. Hao, R. Aswathenarayanaswamy, S. Christie, M.J. Balart, and C.L. Davis: 'Cracking in additive manufactured 316L stainless steel', AAMS 2018, 3-4 Sept, Sheffield, UK, 2018.

56. M.J. Balart, X. Hao, S. Marks, G.D. West and C.L. Davis: in Euro PM2019 Proceedings, Maastricht, The Netherlands, 13-16 October 2019.

57. M.J. Heiden, L.A. Deibler, J.M. Rodelas, J.R. Koepke, D.J. Tung, D.J. Saiz, and B.H. Jared: Addit. Manuf., 2019, vol. 25, pp. 84-103.

58. M.C. Biesinger, B.P. Payne, A.P. Grosvenor, L.W.M. Lau, A.R. Gerson and R. St. C. Smart: Appl. Surf. Sci., 2011, vol. 257 (7), pp. 2717-30.

59. A. Leicht, R. Shvab, E. Hryha, L. Nyborg and L.E. Rännar: in $7^{\text {th }}$ Int. Swedish Production Symposium (Lund; Sweden; 25-27 October 2016).

60. M. Norell, L. Nyborg, and M. Friesel: Powder Metall., 1998, vol. 41 (1), pp. 31-39.

61. L. Nyborg, M. Norell, and I. Olefjord: Surf. Interface Anal., 1992, vol. 19 (1-12), pp. 607-14.

62. M. Wu, Y. Yang, G. Yang, K. Huang, and D. Yin: J. Alloys Compd., 2019, vol. 784, pp. 975-79.

63. R. Kiessling and N. Lange: Non-metallic inclusions in steel. Part I, Iron and Steel Institute, London, UK, 1964.

64. I. Madariaga and I. Gutiérrez: Scripta Mater., 1997, vol. 37 (8), pp. 1185-92.

65. C. Larquet and S. Carenco: Front. Chem., 2020, vol. 8, article 179, https://doi.org/10.3389/fchem.2020.00179.

66. A.S. Wu, D.W. Brown, M. Kumar, G.F. Gallegos, and W.E. King: Metall. Mater. Trans. A, 2014, vol. 45A (13), pp. 6260-70.

67. Y. Hedberg, O. Karlsson, P. Szakalos, and I.O. Wallinder: Mater. Lett., 2011, vol. 65 (14), pp. 2089-92.

68. C. Pauzon, E. Hryha, P. Forêt, and L. Nyborg: Mater. Des., 2019, vol. 179, p. 107873, https://doi.org/10.1016/j.matdes.2019.107873.

69. A. Leicht, U. Klement, and E. Hryha: Mater. Charact., 2018, vol. 143, pp. 137-43.

70. A. Leicht, M. Rashidi, U. Klement, and E. Hryha: Mater. Charact., 2020, vol. 159, p. 110016

71. P. Quinn, S. O'Halloran, J. Lawlor, and R. Raghavendra: $A d v$. Mater. Process. Technol., 2019, vol. 5 (2), pp. 348-59, https:// doi.org/10.1080/2374068X.2019.1594602.

72. A. Röttger, K. Geenen, M. Windmann, F. Binner and W Theisen: Mater. Sci. Eng., A, 2016, vol. 678, pp. 365-76.

73. J. Yu, M. Rombouts, and G. Maes: Mater Des., 2013, vol. 45, pp. $228-35$

74. A.T. Sutton, C.S. Kriewal, M.C. Leu, J.W. Newkirk, and B. Brown: Addit. Manuf., 2020, vol. 31, p. 100904.

75. A.T. Sutton, C.S. Kriewall, S. Karnati, M.C. Leu, and J.W. Newkirk: Addit. Manuf., 2020, vol. 32, p. 100981.

76. V. Laghi, M. Palermo, L. Tonelli, G. Gasparini, L. Ceschini, and T. Trombetti: Int. J. Adv. Manuf. Technol., 2020, vol. 106, pp. 3693-705.

Publisher's Note Springer Nature remains neutral with regard to jurisdictional claims in published maps and institutional affiliations. 